\title{
Upper Cenozoic Deposits of the Central Delmarva Peninsula, Maryland and Delaware
}

GEOLOGICALSURVEY PROFESSIONAL PAPER 1067-A
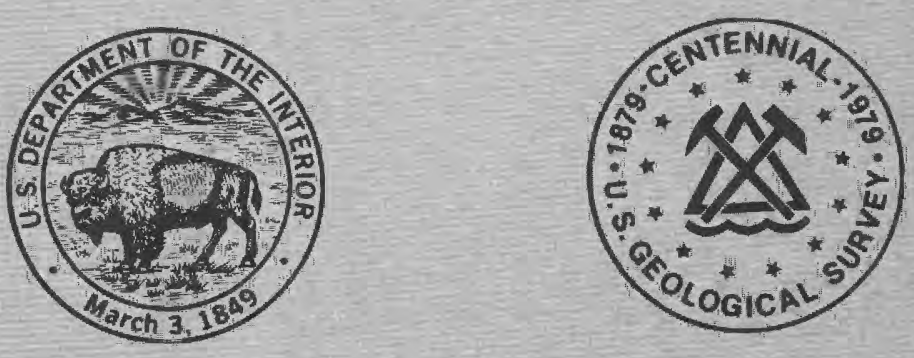


\section{Upper Cenozoic Deposits of the Central Delmarva \\ Peninsula, Maryland and Delaware}

By JAMES P. OWENS and CHARLES S. DENNY

SURFACE AND SHALLOW SUBSURFACE GEOLOGIC STUDIES IN THE EMERGED COASTAL PLAIN OF THE MIDDLE ATLANTIC STATES

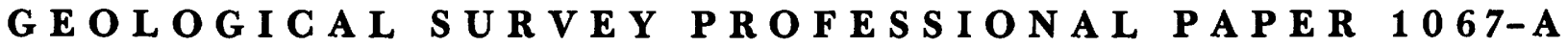

Upper Tertiary deltaic and shallow-water marine deposits form the backbone of the peninsula.

The oldest marine deposits of Pleistocene age reach a maximum altitude of 15 meters (50 feet)

and have been dated radiometrically

at about 100,000 years

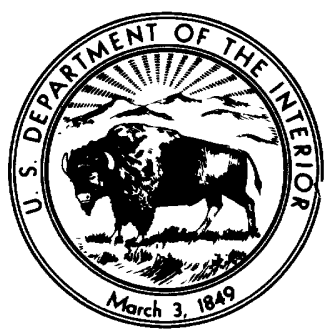




\section{UNITED STATES DEPARTMENT OF THE INTERIOR}

CECIL D. ANDRUS, Secretary

GEOLOGICAL SURVEY

H. William Menard, Director

\section{Library of Congress Cataloging in Publication Data}

Owens, James Patrick, 1924-

Upper Cenozoic deposits of the central Delmarva Peninsula, Maryland and Delaware.

(Surface and shallow subsurface geologic studies in the emerged coastal plain of the Middle Atlantic States)

(Geological Survey professional paper ; 1067-A)

Bibliography: $p$.

Includes index.

Supt. of Docs. no.: I 19.16:1067-A

1. Geology, Stratigraphic-Cenozoic. 2. Geology-Delmarva Peninsula. I. Denny, Charles Storrow, 1911joint author. II. Title. III. Series. IV. Series: United States. Geological Survey.

Professional paper ; 1067-A.

QE690.093 $\quad 551.7$ '8 77-608325

For sale by the Superintendent of Documents, U.S. Government Printing Office

Washington, D.C. 20402

Stock Number 024-001-03191-4 


\section{CONTENTS}

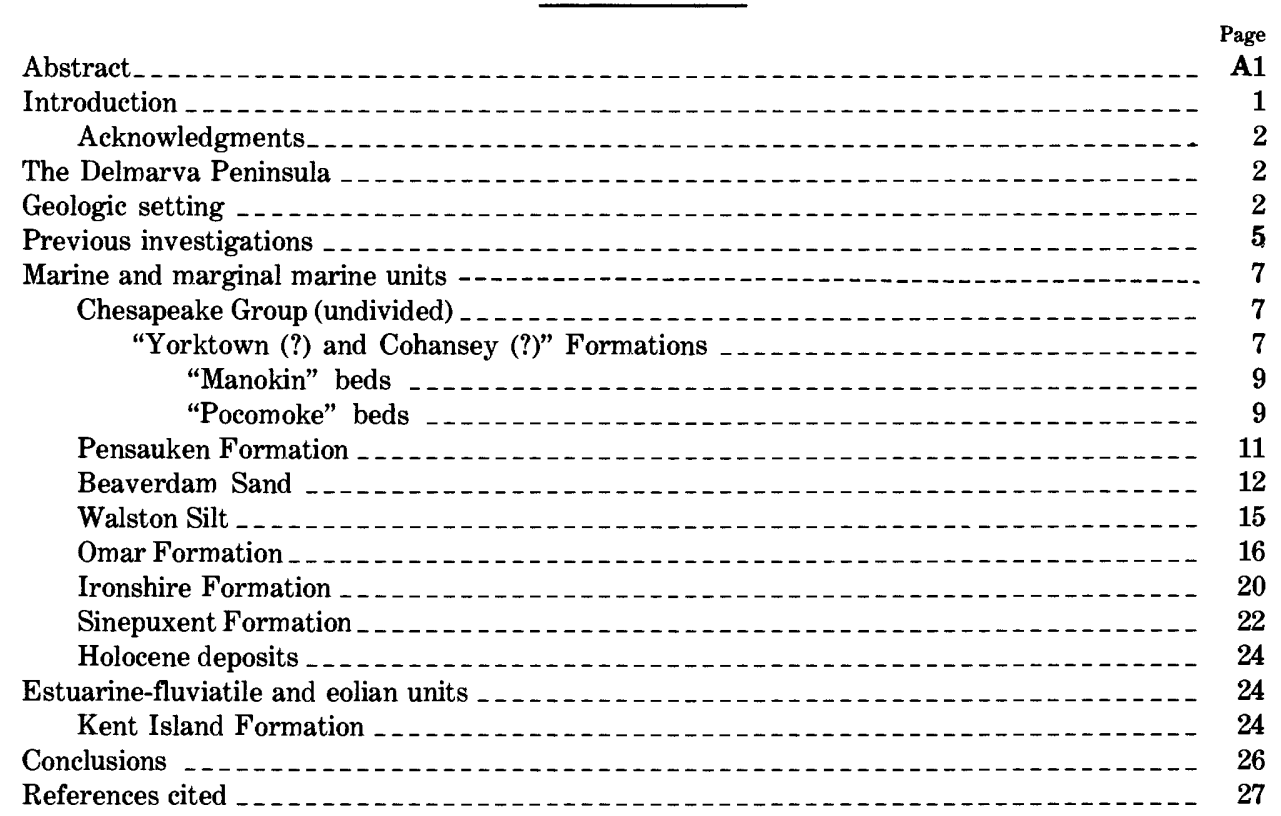

\section{ILLUSTRATIONS}

FIGURE 1. Map of northern Atlantic Coastal Plain

2. Map showing gravel sheets on the northern Atlantic Coastal Plain

3. Diagrammauic cross sections illustrating the marine-terrace concept

4. Diagrammatic cross sections illustrating stratigraphic relationships of surface and near-surface sediments

5. Geologic map of Delmarva Peninsula _ _ 8

6. Diagrammatic cross section illustrating stratigraphic relations of formations described in this report

7. Chart showing stratigraphic and time divisions of Berggren (1972)

8. Columnar sections of "Manokin" and "Pocomoke" beds

9. Photograph of sand and gravel of the Pensauken Formation

10. Map of Beaverdam Sand _.

11. Sketch from photograph showing cross-stratified sand in Beaverdam Sand

12. Sketch from photograph showing tubular borings in Beaverdam Sand

13. Map of Walston Silt _

14. Photograph of Walston Silt near Powellville _ _

15. Columnar sections of the Sinepuxent and Omar Formations and Walston Silt

16. Map of Omar Formation _.

17. Photograph of horizontally bedded beach(?) sand, Omar(?) Formation

18. Photograph of inclined beds of Ironshire Formation

19. Photograph of cross-stratified sand and gravel of Ironshire Formation

20. Cross section of Omar and Ironshire Formation near Rehoboth Béach, Del

21. Cross section of Sinepuxent Formation near Berlin, Md

22. Cross section of Kent Island Formation near Kent Island, Md 


\title{
SURFACE AND SHALLOW SUBSURFACE GEOLOGIC STUDIES \\ IN THE EMERGED COASTAL PLAIN OF THE MIDDLE ATLANTIC STATES \\ UPPER GENOZOIC DEPOSITS OF THE CENTRAL DELMARVA PENINSULA, MARYLAND AND DELAWARE
}

\author{
By James P. Owens and Charles S. Denny
}

\section{ABSTRACT}

The surface and shallow subsurface sediments of the lower Delmarva Peninsula include beds ranging in age from Miocene to Holocene. The oldest beds appear to be typical shelf deposits of the Chesapeake Group (Calvert-Choptank age). These marine units are overlain by deltaic deposits, which range from fluviatile facies in the north (Pensauken Formation) to marginal marine and marine beds in the south ("Yorktown(?) and Cohansey(?)" Formations as used by Rasmussen and Slaughter in 1955). This large deltaic mass underlies most of the Delmarva Peninsula. Fossil age determinations supplemented by some radiometric dates indicate the delta to be largely late Miocene in age. The nonmarine facies of the delta, the Pensauken Formation, previously was considered to be Pleistocene in age.

The late Miocene delta and possibly the Yorktown Formation (lower to middle Pliocene) are overlain by a feldspathic sand, the Beaverdam, which is at least in part marginal marine. Microflora recovered from this formation include species no longer indigenous to the Delmarva region ("exotics"). On the basis of existing information, microfloral assemblages containing "exotics" are pre-Pleistocene in age. The Beaverdam therefore is pre-Pleistocene in age, probably late Pliocene. A highly dissected and weathered unit, the Walston Silt, caps the uplands of the central Delmarva Peninsula, where it overlies the Beaverdam. The Walston has a microflora containing "exotics" and therefore is considered to be the youngest Tertiary unit (uppermost Pliocene) in this area.

Sediments forming a barrier-back-barrier sequence fringe most of the southern Maryland-Delaware part of the Delmarva Peninsula and are found at altitudes of as much as $15 \mathrm{~m} \mathrm{(50} \mathrm{ft)} \mathrm{above} \mathrm{sea} \mathrm{level.}$ This sequence, the Omar Formation, is Sangamon in age and has been dated radiometrically as 60,000 to about 100,000 years old. The microflora in these beds contains no "exotics," and the assemblage suggests a warm-temperate environment. The Omar represents the highest stand of the Quaternary seas in the Delmarva region.

The Ironshire and Kent Island Formations overlie or cut into the Omar Formation and are probably late Sangamon and middle Wisconsin, respectively, in age. Near Ocean City, the Ironshire forms a seaward-facing scarp with a toe nearly $4.5 \mathrm{~m}(15 \mathrm{ft})$ above sea level. A warm-temperate microfloral assemblage from the fluviatile-estuarine facies of the Ironshire Formation in the Delaware Bay region suggests that the formation is interglacial, probably late Sangamon in age.

The Ironshire and Omar Formations are overlain unconformably by the Sinepuxent Formation. The top of this marine unit is slightly above present sea level and has been dated by radiocarbon as about 30,000 years old or middle Wisconsin. The microflora from this formation is a cold- to cool-temperate assemblage (high proportion of spruce pollen).

The outer fringes of the Delmarva Peninsula are being overlapped by deposits of a Holocene marine transgression.

\section{INTRODUCTION}

The record of late Cenozoic high stands of the sea has been searched for in many parts of the world. One of the first coastal regions investigated in detail was the middle Atlantic seaboard. Here in the Maryland Coastal Plain, Shattuck (1901) first described what he considered to be marine deposits of Pleistocene age that formed terraces ranging in altitude from about 10 to $55 \mathrm{~m}(180 \mathrm{ft}$ ) above sea level. Other geologists adopted the marine terrace scheme, the most notable being Cooke (1930), who proposed that marine terraces extended along nearly the entire eastern seaboard, especially between Maryland and Florida. Cooke considered these terraces as prima facie evidence of high stands of the Quaternary seas caused by changes in size of polar and subpolar ice caps.

Our investigations were undertaken because no systematic study of the surface geology of the central Delmarva Peninsula had ever been made. The area is close to that studied originally by Shattuck. At the outset, we assumed that the surface units discussed by all previous investigators were Quaternary in age and were deposited unconformably upon the Chesapeake Group of late Tertiary age. As the work progressed, some of the units previously thought to be Pleistocene turned out to be in fact Tertiary, and this finding necessitated an examination of more units than we had anticipated. In a practical sense, this meant deeper subsurface investigations.

This report summarizes the physical stratigraphy and the biostratigraphy of the formations recognized and mapped in our study of the central Delmarva Peninsula in Maryland and southern Delaware. Samples came from many borrow pits and from about 400 auger borings. Additional data were gathered by R. B. Mixon, who carried on a companion study to the south on the Cape Charles Peninsula in Virginia. Geologic maps of the peninsula at 1:250,000 scale and of the Maryland counties at 1:62,500 scale have been prepared (Owens, Denny, and others, unpub. data, 1977).

Another report in this series (Owens and Minard, 1978) discusses the surficial deposits in the area to the north and northeast, largely in New Jersey, which are 
essentially the fluviatile equivalents of many of the formations in the lower Delmarva Peninsula.

\section{ACKNOWLEDGMENTS}

Appreciation is expressed to Kenneth N. Weaver, Director, Maryland Geological Survey, to Robert R. Jordan, State Geologist, Delaware Geological Survey, and to the staffs of the two Surveys for their assistance to our project.

We also wish to thank our colleagues in the U.S. Geological Survey for their assistance, especially R. B. Mixon, J. T. Hack, William Raspet, W. S. Kirk, Karl Stefansson, and Nicholas Lampiris.

\section{THE DELMARVA PENINSULA}

The Delmarva Peninsula is a lowland bordered by estuaries and the sea (fig. 1). It has an altitude of less than $30 \mathrm{~m}$ (100 ft) above sea level except at the extreme northern end. The estuaries, Chesapeake and Delaware Bays, separate the peninsula from higher ground to the northeast in New Jersey and to the southwest in Maryland and Virginia. Our study was concentrated in the lower part of the peninsula between lat $39^{\circ} \mathrm{N}$. and the Maryland-Virginia State line, where the maximum altitude is slightly more than $24 \mathrm{~m}(80 \mathrm{ft})$ above sea level. The broad Delmarva lowland crosses the emerged CoastaI Plain. Whether this lowland is an erosional or a tectonic feature is one of the crucial questions that must be answered before the terrace controversy can be resolved.

The core of the Delmarva Peninsula is an upland ranging in altitude from about 12 to $24 \mathrm{~m}(40-80 \mathrm{ft})$. The central upland is edged by broad lowlands, which are separated from the surrounding water bodies by wetlands. An extensive barrier-back-barrier system parallels much of the Atlantic shore. On the Atlantic side of the peninsula, a long irregular seaward-facing scarp with a

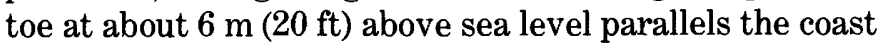
from near Ocean City, Md., south to the Virginia-Maryland border. Remnants of the same scarp extend northward from Ocean City to Rehoboth Beach, Del. To the north along the southwest side of Delaware Bay, the Holocene coastal swamps are bordered by a poorly defined east-facing scarp with a toe at about $5 \mathrm{~m}(15 \mathrm{ft})$ above sea level. To the west, a broad lowland as much as $12 \mathrm{~km}$ (7.5 miles) wide rises from an altitude of about 6 $\mathrm{m}(20 \mathrm{ft})$ near the coast to about $12 \mathrm{~m}(50 \mathrm{ft})$ at the edge of the central upland.

On the west side of the central upland, a prominent west-facing scarp with a toe at about $6 \mathrm{~m}(20 \mathrm{ft})$ above sea level, extends from Kent Island south to the Choptank River. South of the river, the scarp is low and greatly dissected. The land rises gently from Chesapeake Bay eastward to the surface of the central upland.

\section{GEOLOGIC SETTING}

The Delmarva Peninsula is entirely within the Atlantic Coastal Plain. Our investigation deals with formations of Cenozoic age that constitute the upper 30-61 m (100-200 $\mathrm{ft}$ ) of sediment at the top of the continental wedge. The formations range from Paleocene (the Aquia Formation) to Holocene. The most significant of the surface formations are the great gravel sheets, which are a part of the sheets that cap large areas of the northern Atlantic Coastal Plain. The present landscape in this part of the Coastal Plain is largely the product of their emplacement.

The best known of these gravel sheets, the Brandywine Formation, is found in the uplands of southern Maryland west of Chesapeake Bay (Hack, 1955; Schlee, 1957). The gravel was deposited in a series of migrating stream channels that cut downward and laterally, carrying sediment largely derived from the Appalachian Mountains (fig. 2). The sediment in these channels was mature, consisting of orthoquartzitic sand and gravel characterized by quartz, quartzite, and chert (Schlee, 1957). The gravel sheet rarely exceeds $15 \mathrm{~m}(50 \mathrm{ft})$ in thickness (Hack, 1955). The age of this deposit is conjectural but has long been considered Pliocene (?), mainly because of the high topographic position of the gravel sheet, its degree of weathering, and its stratigraphic position overlying the St. Marys Formation (middle Miocene).

Northeast of Chesapeake Bay are two other gravel sheets, one covering much of southern New Jersey (the Bridgeton Formation), and the other covering much of the northern Delmarva Peninsula (the Pensauken Formation) (fig. 2). The Pensauken Formation is entrenched in the Bridgeton Formation and therefore is younger, but how much of a time interval separates the two units is uncertain. These two gravel sheets have been discussed by Owens and Minard (1978).

The Bridgeton Formation or gravel sheet in southern New Jersey crops out at altitudes ranging from nearly 61 $\mathrm{m}(200 \mathrm{ft})$ above sea level in the northern sector to nearly

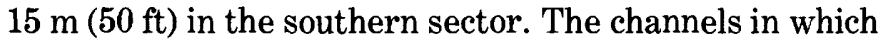
the gravel was deposited appear to have migrated roughly from east to west. Channel depth or gravel thickness within the sheet varies, but in places it is as much as 27 $\mathrm{m}(90 \mathrm{ft})$. The sediment in the Bridgeton Formation is immature and locally very feldspathic, differing in this respect from the very quartzose Brandywine Formation.

The Pensauken Formation is of particular importance to the geology of the lower Delmarva Peninsula because the emplacement of this gravel sheet initially produced 
the Delmarva lowland between the highlands in southern Maryland (west of Chesapeake Bay) and in New Jersey. The formation is discussed in detail later in this report. Deposits of Holocene age partly fill the submerged val- leys of Chesapeake and Delaware Bays (Owens and others, 1974). The carving and aggradation of the bays postdates the emplacement of the Pensauken Formation and possibly took place at different times; certainly the his-

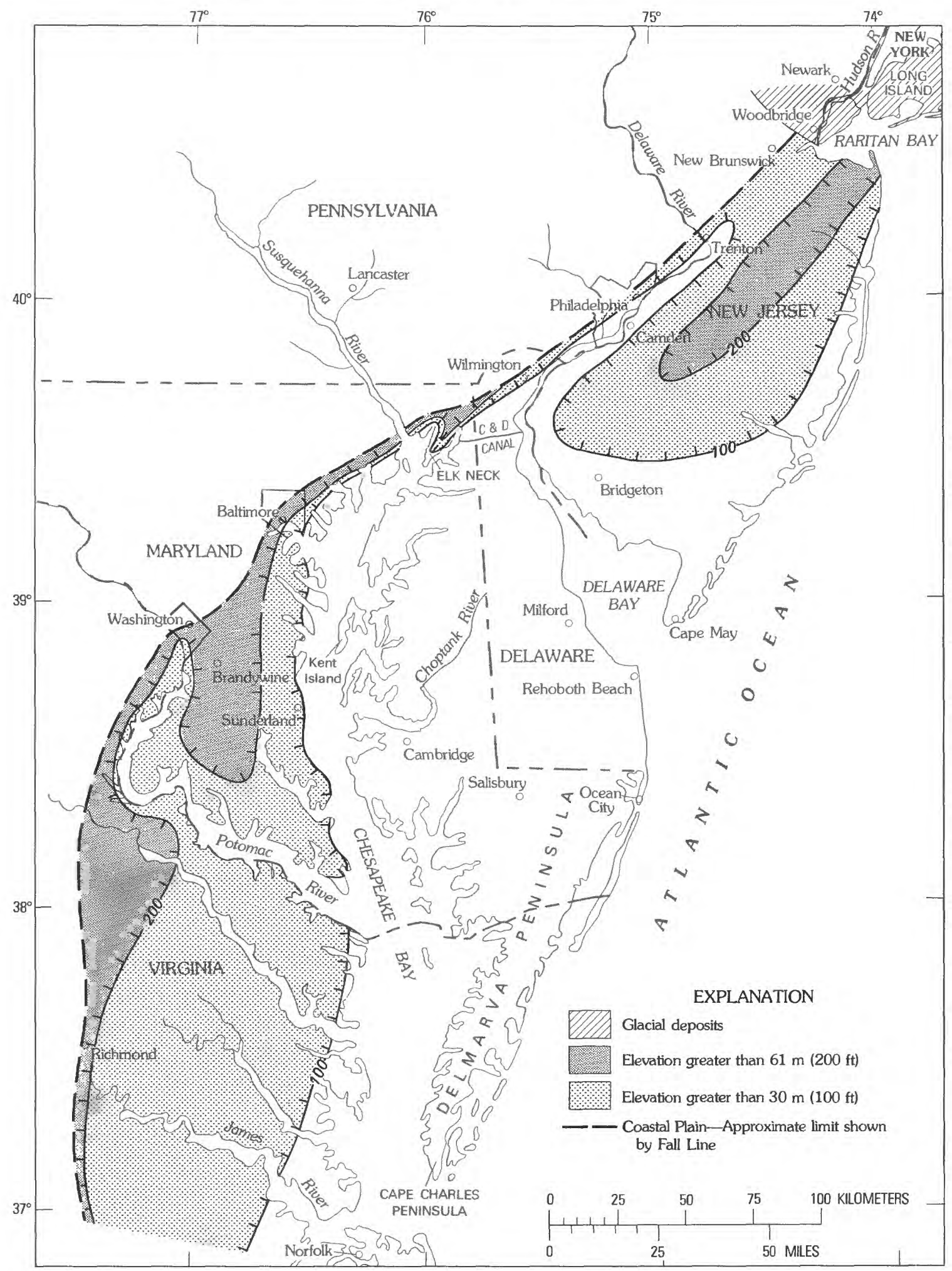

FIGURE 1.-Map of northern part of the Atlantic Coastal Plain. Delmarva Peninsula between Chesapeake and Delaware Bays is largely less than $30 \mathrm{~m}$ (100 ft) above sea level. 
tory of their evolution is very complex. The most recent cutting and filling of these drainageways was during and after the last glaciation (about 18,000 years B.P.). Bay fill of perhaps this age occurs to depths of $61 \mathrm{~m}(200 \mathrm{ft})$ below sea level (Hack, 1957). A thin wedge of barrier and back-barrier deposits fringes the coastal areas; these de-

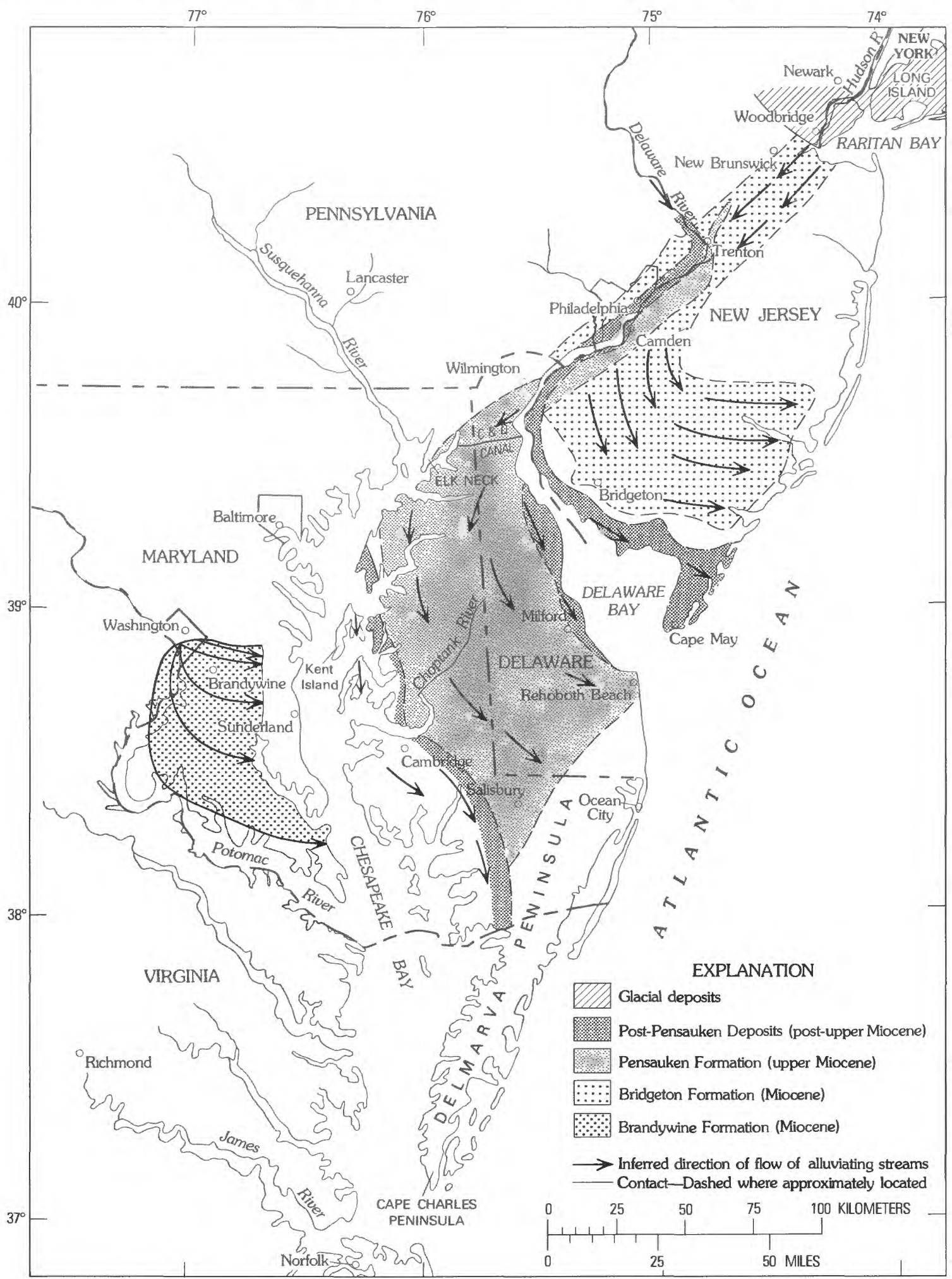

FIGURE 2.-Gravel sheets on the northern part of the Atlantic Coastal Plain. As shown in the diagram, the Brandywine Formation of southern Maryland, which is considered to be Pleistocene in age by others, is now interpreted to predate or possibly be the time equivalent of the Pensauken or Bridgeton Formation. 
posits were emplaced during the ongoing Holocene transgression (Kraft, 1968, 1971).

\section{PREVIOUS INVESTIGATIONS}

Previous geologic investigations that bear on our study include some, largely published prior to 1960 , that deal with the marine-terrace concept, and others, published during the last 10 years, that are concerned primarily with ground-water resources. The marine-terrace concept of Shattuck (1901, 1902, 1906) and Cooke (1930, 1958 ) is illustrated in figure 3. Shattuck's interpretation is relatively simple (fig. $3 A$ ). He thought that four marine terraces existed in coastal Maryland; three were underlain by deposits of Quaternary age (Sunderland, Wicomico, and Talbot) and one by deposits of Tertiary age ("Lafayette" of former usage). The oldest Quaternary terrace deposits, the Sunderland, cropped out at altitudes as much as $55 \mathrm{~m}$ (180 ft) above sea level; thus, this altitude was the maximum high stand of the Quaternary seas. The ages of Shattuck's units were largely inferred. Only the Talbot deposits contained a marine fauna, which Shattuck considered to be Pleistocene in age.

Cooke (fig. 3B) modified and expanded Shattuck's interpretation. He proposed that the maximum altitude of the Quaternary seas was $82 \mathrm{~m}(270 \mathrm{ft})$ represented by the Brandywine Formation of Maryland. In addition, he traced the terraces along much of the Atlantic seaboard, utilizing many Maryland names, and proposed that formation of the terraces was controlled by glacioeustatic changes in sea level. No faunal evidence supported his age assignments for the formations above an altitude of $7 \mathrm{~m}$ ( $25 \mathrm{ft})$. In spite of this lack of supporting evidence, his interpretation has gained wide acceptance.
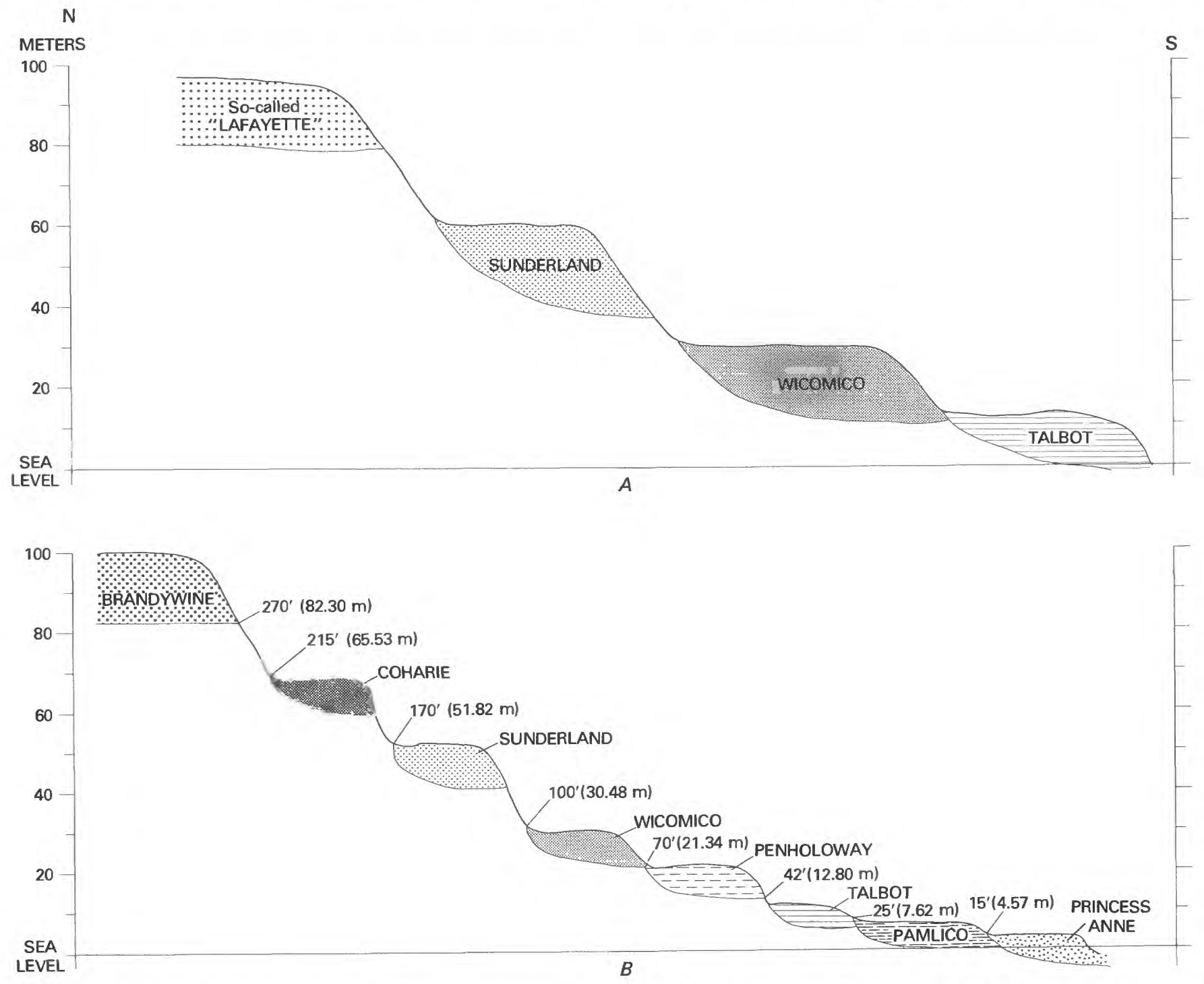

FIGURE 3.-The marine terrace concept. Diagrammatic cross sections to illustrate the marine terraces recognized: $A$, by Shattuck (1901, 1902, 1906); $B$, by Cooke $(1930,1958)$. 
Flint (1940) examined the Coastal Plain over a large area of the eastern seaboard and stressed his opposition to the presence of any Pleistocene marine unit above 30 m (100 ft). Hack (1955) studied the high-level deposits ( $>100 \mathrm{ft}$ above sea level) in southern Maryland west of Chesapeake Bay, which included the Brandywine and Sunderland deposits of Shattuck and Cooke. He demonstrated that these units were not separable and certainly were not marine but were part of a degrading fluviatile system.

Coch (1965) and Oaks and Coch (1973) discussed and mapped the sediments west of lower Chesapeake Bay in the vicinity of Norfolk, Va. Their studies represent the most detailed examination of the coastal sediments in Eastern United States to date. One of the major results of these investigations was to demonstrate that some of the terraces consisted of more than one mappable rock unit. However, the age relationships of the mapped units are still poorly known.

In the last 20 years, four separate investigations dealing in part with the surface formations of the central Delmarva Peninsula have been completed. Most of the pioneering stratigraphic studies were carried on by Rasmussen and his associates (Rasmussen and Slaughter, 1955, 1957; Rasmussen and others, 1960). In their last publication (1960) on southern Delaware, the surface and near-surface sediments were depicted as a series of lenticular fluviatile-estuarine deposits largely of Pleistocene age (fig. $4 A$ ). It is of particular interest that the Beaverdam (defined as any reddish gravelly sediment) was believed by these authors to rest unconformably upon the Brandywine. We have reached the same conclusion.

Hansen (1966) examined much of the same interval of sediments near Salisbury, Md. (fig. 4 C.) In his view, the Beaverdam facies and the red gravelly facies (Brandywine as used by Rasmussen and Slaughter, 1955) were part of the same transgressive sequence; the Beaverdam was the estuarine equivalent of an advancing sea which overlapped and in part removed the fluviatile red gravelly facies. Hansen lumped these two units into one (the Salisbury Formation) and considered this unit to be Sangamon(?) in age. He also studied the Walston Silt, which he thought was late Sangamon(?) and formed as a series of regressing tidal marshes.

In Delaware, Jordan and others (1967) modified Rasmussen's ideas and proposed a different stratigraphic nomenclature (fig. $4 B$ ). They reinstated an old name for the red gravelly sediments, the Columbia Formation of McGee (1888), and interpreted the Beaverdam Formation as the subsurface equivalent of the Columbia. They considered both units and an overlying clayey unit, the
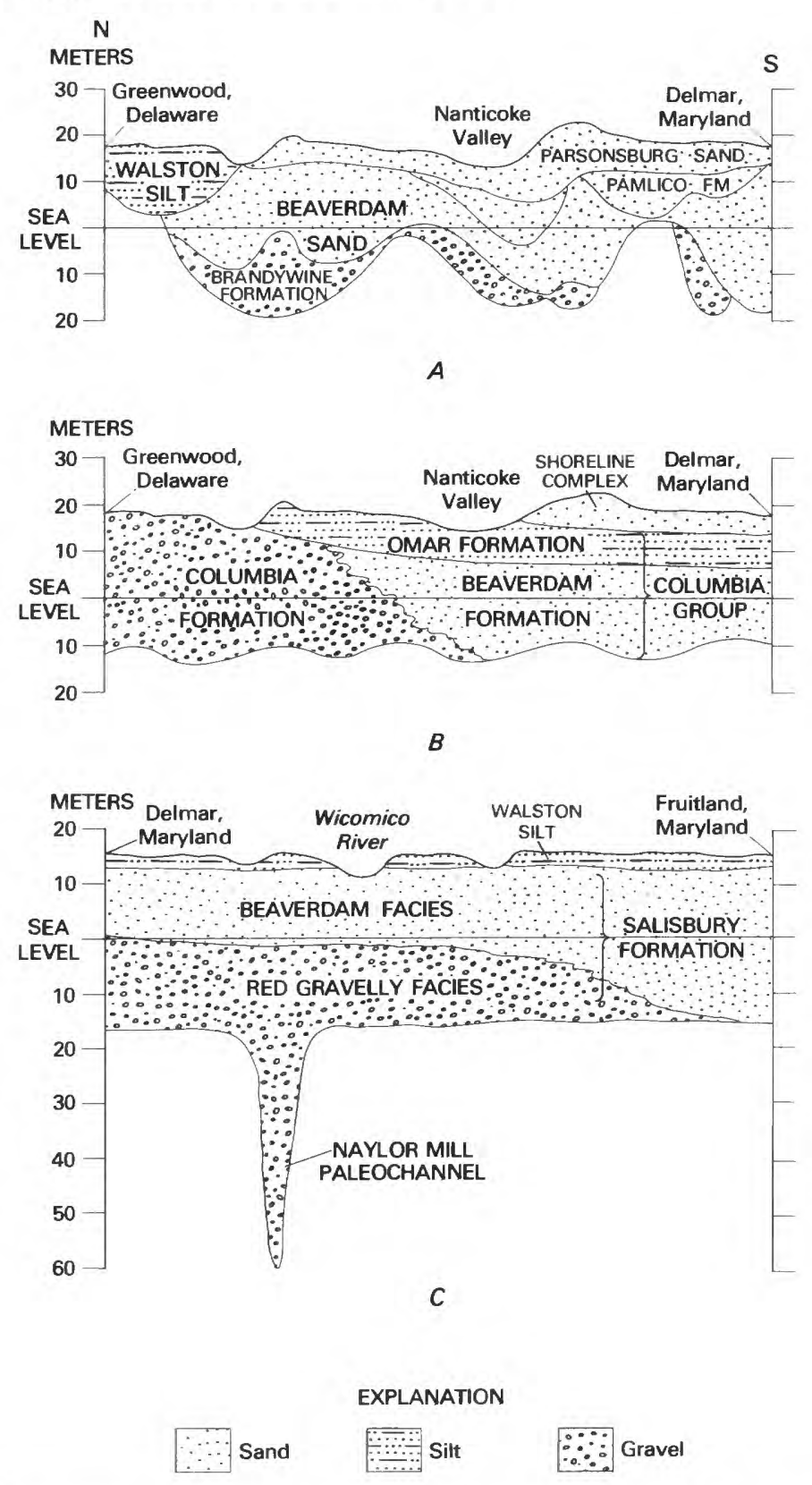

FIGURE 4.-Diagrammatic cross sections to illustrate the stratigraphic relationships of the surface and near-surface sediments of the Delmarva Peninsula. $A$, from Rasmussen and others (1960); $B$, from Jordan and others (1967); $C$, from Hansen (1966).

Omar Formation, to constitute the Columbia Group, and all were considered to be Pleistocene in age.

Holocene sediments fringe the Delmarva Peninsula and have been studied in detail by Kraft and his associates in Delaware (Kraft, 1968, 1971; Kraft and others, 1973), who have prepared a detailed interpretation of coastal processes during the Holocene transgression. 


\section{MARINE AND MARGINAL MARINE UNITS}

The formations described herein were deposited in large part in a marginal marine environment. Two units are fluvial deposits that grade into estuarine beds. The Pensauken Formation, a fluviatile deposit, interfingers downdip with marine strata and is grouped here with the marginal marine units. Our interpretation of the geology in the lower Delmarva Peninsula is shown in a generalized map and cross section (figs. 5 and 6). Not all the units discussed are shown on the map. Some formations that occur only in the subsurface are described in this paper because they are important to an understanding of the geologic history of the surficial deposits.

\section{CHESAPEAKE GROUP (UNDIVIDED)}

In all, in the central part of the Delmarva Peninsula, four formations presumably constitute the Chesapeake Group: Calvert (oldest), Choptank, St. Marys, and Yorktown (youngest). Although these sediments have been studied by many investigators, the separation into distinct lithostratigraphic units has not been widely accepted. We know, for example, that the St. Marys Formation in Virginia has a distinctly younger fauna than does the St. Marys in Maryland (Mansfield, 1943). Blackwelder and Ward (1976) have divided the St. Marys of Virginia into two units: "Claremont" (older) and "Cobham" (younger), both younger than the St. Marys of Maryland. The upper sediments of the Chesapeake Group and their relationship to the widespread gravel-covered areas of the Delmarva Peninsula are of special interest in our study.

Most of the sediment in the lower part of the Chesapeake Group is interbedded gray to dark-gray massive to finely laminated silt and clayey silt and yellow to white, loose, micaceous, slightly feldspathic quartz sand. The quartz sand is similar to the North Keys Sand described by Hack (1955) in southern Maryland or to the outcropping Kirkwood Formation in New Jersey; it is also what Cushing and others (1973) more recently referred to as the "Cheswold" and "Fredrica" aquifers.

Within the central part of the Delmarva Peninsula, the lower sediments of the Chesapeake Group are exposed intermittently along the major rivers in the western part of the peninsula between Kent Island and Cambridge, Md. Many small exposures are found along the upper Choptank River and its major tributary, the Tuckahoe. The type locality of the Choptank Formation is along the lower reaches of the Choptank River near Cambridge, Md., where the formation is more sandy than elsewhere and is abundantly fossiliferous (Gernant, 1970). South of Cambridge, the St. Marys(?) Formation has been re- ported in the subsurface at several localities (Rasmussen and Slaughter 1955, 1957; Mack and others, 1971), where it apparently was identified as the dark-gray locally fossiliferous clay and clayey silt between the more sandy Choptank Formation below and the very sandy so-called "Yorktown and Cohansey(?)" Formations above. There is little paleontologic support for this identification.

"YORKTOWN AND COHANSEY(?)" FORMATIONS

In the central part of the Delmarva Peninsula, Rasmussen and Slaughter (1955) applied the name "Yorktown (?) and Cohansey(?)" Formations to a widespread blanket of sandy sediments overlying the silty clay of the St. Marys(?) Formation. The unit does not reach the surface in the Delmarva Peninsula and is known only from well cuttings or subsurface cores. Knowledge of the physical character and the age of this formation are important to our understanding of adjacent younger formations. We sampled the so-called "Yorktown(?) and Cohansey(?)" Formations in several deep auger holes. Rasmussen supposed that the sandy sediments overlying the St. Marys(?) Formation represented both the Yorktown Formation of Virginia and the Cohansey Sand of New Jersey. This supposition is interesting because, where exposed, these two formations are lithologically quite distinct and of different ages; the Yorktown consists of highly fossiliferous sand and green silty sand, whereas the Cohansey is an unfossiliferous unit consisting of white sand interbedded locally with dark-gray highly carbonaceous silt and clayey silt. Because of its very fossiliferous nature, the age of the Yorktown is better known than that of the Cohansey. Hazel (in press), in a study of the ostracodes from the Yorktown Formation, assigned an early to middle Pliocene age to the unit. Rachele (1974), in a study of the microflora from the Cohansey in New Jersey, considered the unit to be late Miocene or early Pliocene in age. There is a great deal of uncertainty in this age assignment. According to Berggren (1972), the Miocene was 5.0 million to 22.5 million years ago (fig. 7). Rachele's age of $18.4 \mathrm{~m} . \mathrm{y}$. then would fall in the early Miocene, not the late Miocene (Rachele, 1974 , p. 94).

Rasmussen and Slaughter $(1955,1957)$ divided their "Yorktown(?) and Cohansey(?)" Formations of the Delmarva Peninsula into four beds, largely defined on their water-bearing capacity: two sands, the "Manokin" (the lower aquifer), and the "Pocomoke" (the upper aquifer); and two clay-silt units (aquicludes), both unnamed. The "Manokin" sand, the basal unit, has been used to separate the "Yorktown(?) and Cohansey(?)" Formations from the underlying very clayey St. Marys(?) Formation.

Along the coast near Ocean City, Md., Weigle (1974) has recognized a third aquifer between the "Manokin" 


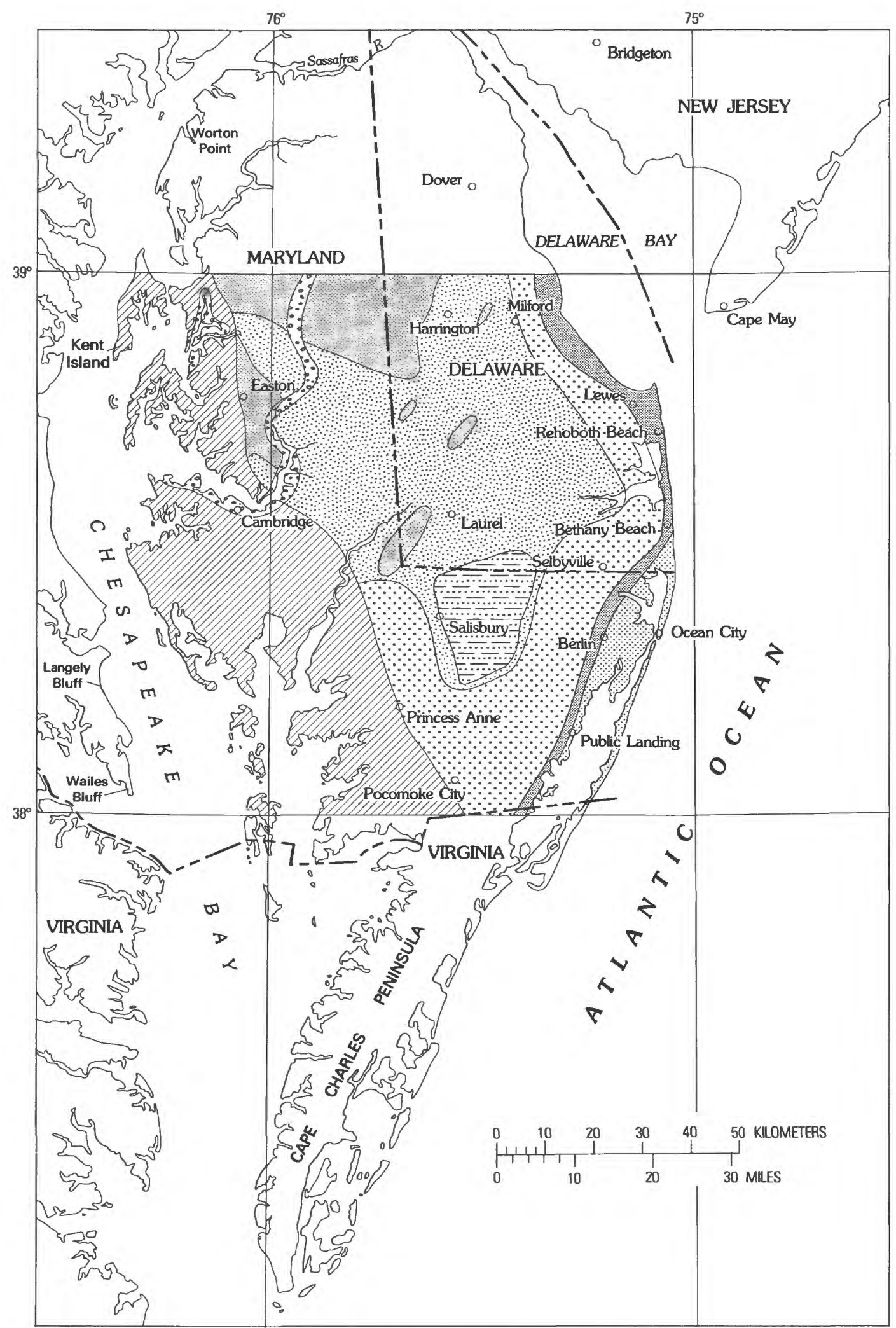

Figure 5.-Generalized geologic map of the central part of the Delmarva Peninsula. Holocene deposits omitted. 


\section{EXPLANATION}

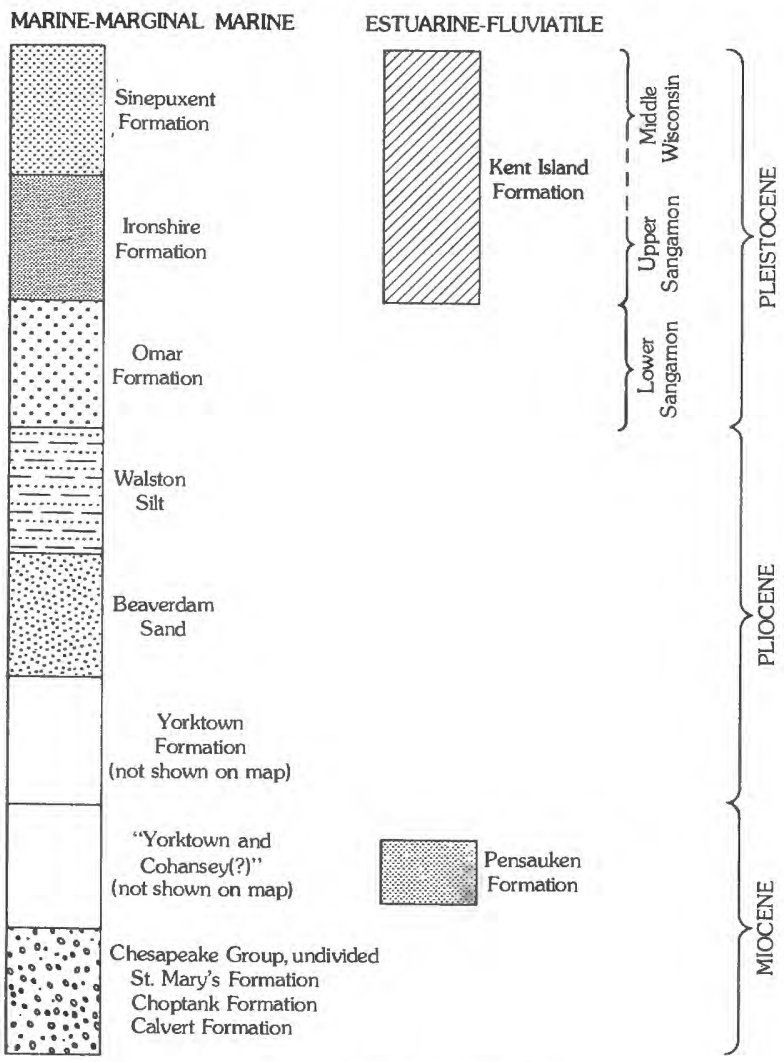

Figure 5.-Continued.

and "Pocomoke" beds. Obviously, the beds within the "Yorktown(?) and Cohansey(?)" Formations of Rasmussen and Slaughter (1955) vary in thickness and in lateral continuity from place to place.

"MANOKIN" BEDS

The lithologies of the "Manokin" beds penetrated in our drill hole (Monie 1) along the Manokin River near Princess Anne, Md., are generally the same as those found in the wells described by Rasmussen and Slaughter (1955). The sandy beds (Manokin aquifer) are about $30.4 \mathrm{~m}$ (100 ft) thick (fig. 8). Most of this interval consists of dark-gray, very clayey, silty, medium-grained sand interbedded locally with thin beds of fine gravel. Characteristically, the "Manokin" sands have an abundance of fine woody fragments. Quartz and, to a lesser degree, feldspar are the major sand minerals. The heavy-mineral suite is immature, characterized by the presence of large concentrations of hornblende in the nonopaque fraction. The introduction of this mineral in quantity distinguishes these sands from the lower beds of the Chesapeake Group, where hornblende occurs in relatively minor concentrations. In southern Maryland west of the bay, Glaser (1971) noted a similar change in heavy-mineral assem- blages within the Chesapeake Group, presumably between the Choptank and St. Marys Formations.

The sandy "Manokin" beds contain megafossils at depths $27-49 \mathrm{~m}(90-160 \mathrm{ft})$ below the surface. According to B. W. Blackwelder and L. W. Ward (written commun., 1974), the beds may be correlated with the St. Marys Formation in the type area-St. Marys County, Md. The mollusk Mesodesma mariana Glenn is found in the "Manokin" beds and in the St. Marys Formation. The two units have the mollusks Bulliopsis integra Conrad and Bulliopsis quadrata Conrad in common as well as the brachiopod Discinisca sp. The deposits of the type St. Marys beds are very near the middle Miocene-upper Miocene boundary. This fact suggests that the "Manokin" beds of the "Yorktown(?) and Cohansey(?)" Formations are not Pliocene equivalents of the Yorktown. The "Manokin" fossil assemblage containing abundant specimens of the mollusk genera Gemma, Bulliopsis, and Nassarius indicates deposition in shallow water, probably with nearby tidal flats. The ostracode assemblage supports this interpretation. Cyprideis, a brackish-water form, is common in samples from this bed (J. E. Hazel, written commun., 1974).

An abundant microfloral assemblage was found in samples from the "Manokin" beds (L. A. Sirkin, written commun., 1976). A wide variety of tree pollen was present, the dominant taxa being oak, pine, and hickory. In addition, pollen was found from several trees that do not now exist in the United States. These pollen types, termed "exotics," include Pterocarya, podocarp, Planera, and Engelhardtia. A pollen assemblage of this type is typical of deposits of Tertiary age (Leopold, 1969) and suggests a warm-temperate climate. The pollen is definitely pre-Pleistocene in age.

"POCOMOKE" BEDS

In the area south and east of Princess Anne, Md., several of our auger holes pentrated a sand that Ramussen and Slaughter (1955) called the "Pocomoke" aquifer. Where we drilled, the sand is about $27 \mathrm{~m}(90 \mathrm{ft})$ thick. Although it also is dominantly a sand, the "Pocomoke" differs lithically from the "Manokin" sand in several important aspects (fig. 8). The "Pocomoke" for example, has much greater concentrations of glauconite sand interbedded with quartz-rich sand, more beds containing gravel as much as $9 \mathrm{~cm}$ (3.5 in.) in diameter, and many soft pale-gray siderite concretions ranging in size from $2.54 \mathrm{~cm}(1 \mathrm{in}$.) to $7.6 \mathrm{~cm}$ (3 in.). The "Pocomoke" beds have a heavy-mineral assemblage similar to that in the "Manokin" beds but have somewhat higher concentrations of hornblende.

Fossils are locally abundant in the "Pocomoke" sands, much more so than in the "Manokin" sands. As in the "Manokin," the fauna of the "Pocomoke" is character- 


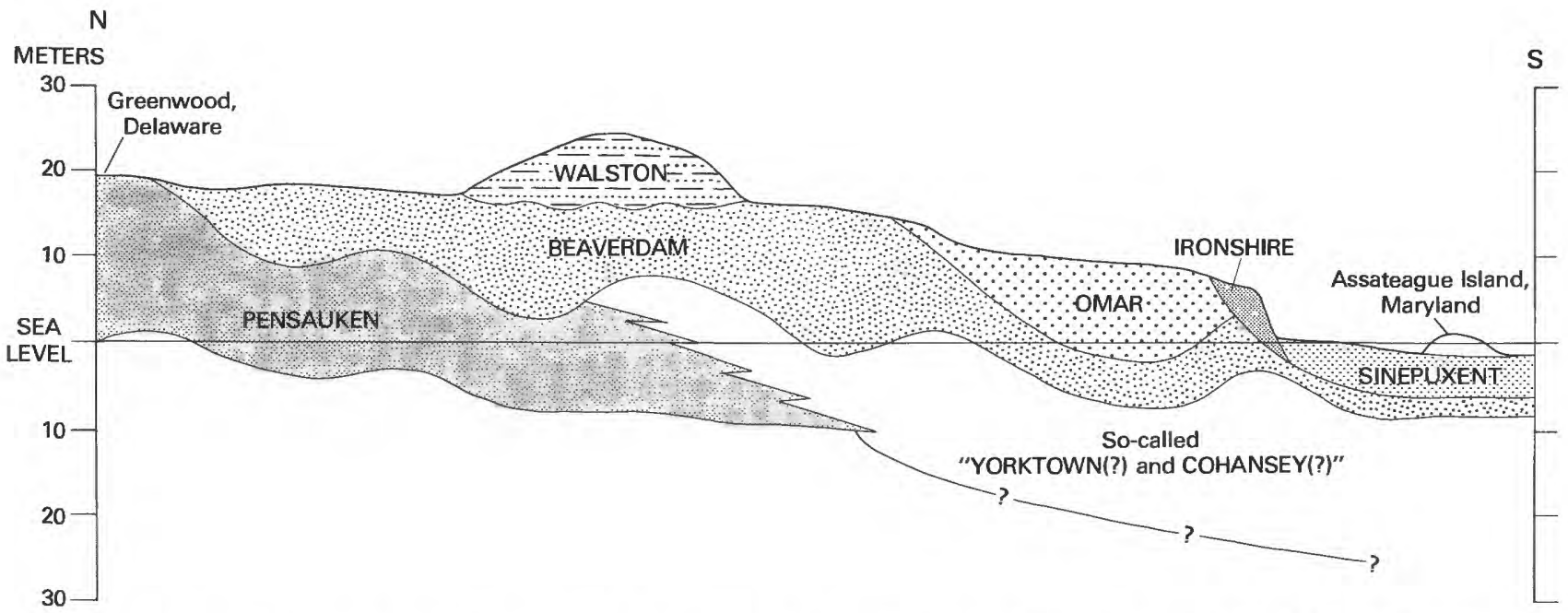

FIGURE 6.-Diagrammatic cross section to illustrate the stratigraphic relations of the formations (except Kent Island Formation) described in this report.

\begin{tabular}{|r|r|r|}
\hline Epoch & $\begin{array}{c}\text { Age estimates for } \\
\text { boundaries (in } \\
\text { millions of years } \\
\text { B.P.) }\end{array}$ & $\begin{array}{c}\text { Dating of some } \\
\text { pertinent units }\end{array}$ \\
\hline POLOCENE \\
PLEISTOCENE
\end{tabular}

FIGURE 7.-Stratigraphic and time divisions of Berggren (1972) for that part of the column pertinent to this report.

ized by an abundance of mollusks. On the basis of Pecten eboreus urbannaensis Mansfield, Astarte rappahannockensis Gardner, and Isognomen sp., the "Pocomoke" is correlated with the upper part of the St. Marys of Virginia (informally referred to as the "Cobham" beds, B. W. Blackwelder and L. W. Ward, written commun., 1976). On the basis of these fossils, the "Pocomoke" beds would be late Miocene in age, definitely older than
Yorktown and younger than "Manokin." Glauconite recovered by us from the middle of the "Pocomoke" beds near Pocomoke City was dated by the K/Ar method. A radiometric age of 6.4 million $\pm 5,000$ years was obtained from this sample (John Obradovich, written commun., 1973), an age compatible with the fossil age determination.

An analysis of the fauna in the "Pocomoke" beds indicates deposition of the shelf in significantly deeper water than that in which the "Manokin" beds were deposited. Pollen is not as abundant in the "Pocomoke" beds as in the "Manokin." Overall, however, the assemblages in the two units are similar, and both contain "exotic" forms (L. A. Sirkin, written commun., 1975).

The "Yorktown and Cohansey(?)" Formation as used by Rasmussen and Slaughter in 1955, therefore, in its type area, is older than the Yorktown Formation of southeastern. Virginia. Although the Yorktown, at least as we know now, is not present in the Delaware and Maryland parts of the Delmarva Peninsula, it is widespread in the Virginia part of the peninsula (Cape Charles). In Virginia, the Yorktown is definitely younger than the "Manokin" and "Pocomoke" beds (J. E. Hazel, B. W. Blackwelder, and L. W. Ward, written commun., 1974) and represents much of the lower to middle Pliocene sediments in this general region.

An additional problem concerning the "Manokin" and "Pocomoke" beds is their lithology. The units underlying the beds, the older formations of the Chesapeake Group, are characterized by their abundance of fine clasts (Gernant, 1970). The "Manokin" and "Pocomoke," however, have significant concentrations of coarse clasts -in many areas, abundant gravel. Where studied by us, these two units are approximately $120 \mathrm{~km}(75$ miles) from outcropping crystalline rocks that are the 


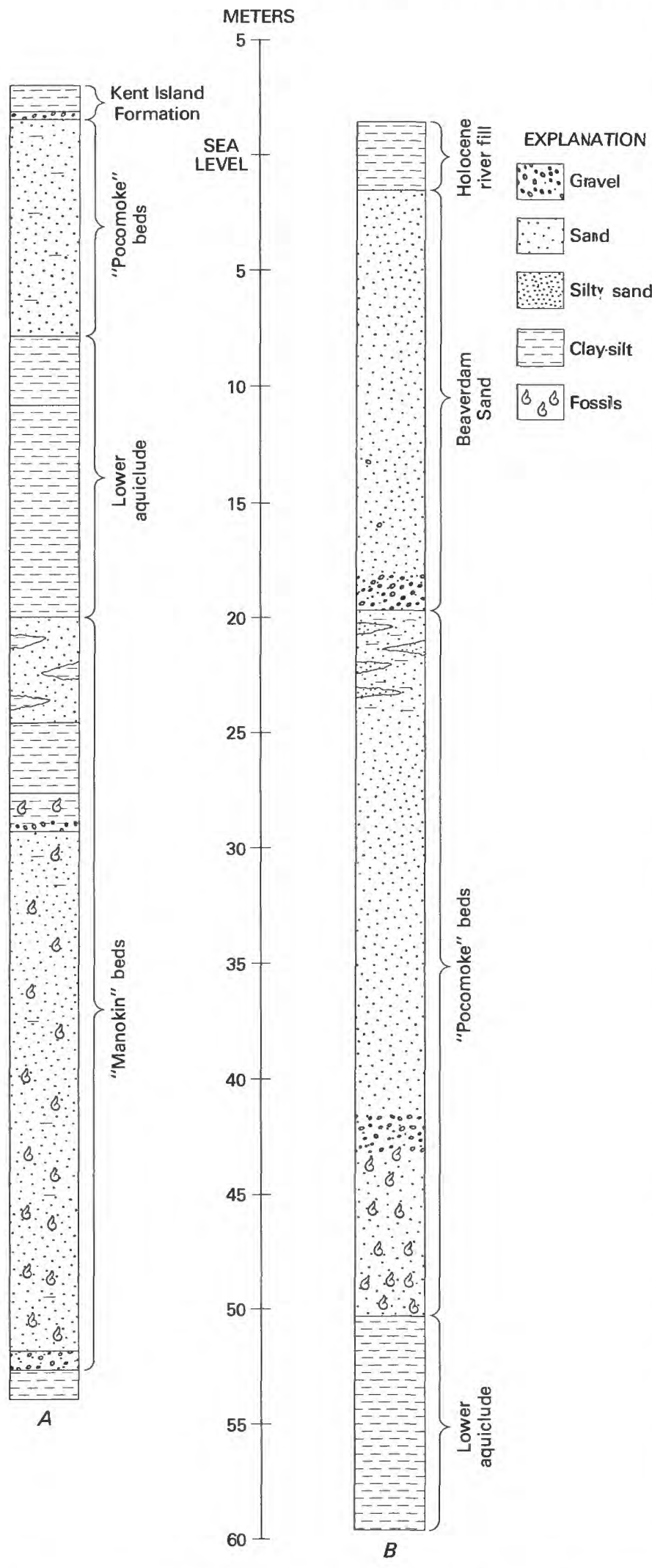

Figure 8.-Columnar sections of the "Manokin" and "Pocomoke" beds. Lithology based on samples from auger holes. A. M1, Monie quadrangle, Maryland.; $B$. SH27, Snow Hill quadrangle, Maryland. nearest source area for the coarse clasts. How these clasts were transported and deposited this far out onto the shelf, therefore, is a major problem. Another characteristic of these beds is the abundance of small to large woody fragments. A possible source for the coarse clasts is suggested in the following section on the Pensauken Formation.

\section{PENSAUKEN FORMATION}

In the northern part of the Delmarva Peninsula, much of the upper surface is capped by orange to reddishbrown sand and gravelly sand, which are correlated with the Pensauken Formation of New Jersey (Owens and Minard, 1978). The Pensauken is a feldspathic quartz sand (protoquartzite to subarkose in composition). Both microcline and plagioclase (oligoclase principally) are present, microcline being the major feldspar type. The nonopaque heavy minerals, especially in the eastern part of the peninsula, are typically an immature suite, notably hornblende rich, similar to that found in the "Manokin" and "Pocomoke" beds.

From near the head of Chesapeake Bay south to an irregular line connecting Milford, Del., and Cambridge, Md. (figs. 1, 5), the Pensauken Formation forms most of the upland surface, which is chiefly 18 to $27 \mathrm{~m}$ ( 60 to 90 $\mathrm{ft}$ ) above sea level. Southeast of the line, the unit is overlapped by younger sediments but can be traced in the subsurface to a second highly irregular line connecting Salisbury, Md., on the southwest and Reboboth Beach, Del., on the northeast (figs. 1, 5). Farther down the peninsula, the orange-brown or red gravelly sediments of this unit are absent or very thin (Rasmussen and Slaughter, 1957; Hansen, 1966).

The Pensauken Formation is best exposed in the northern part of the peninsula, especially along the Sassafras and Elk Rivers where the top of the unit is more than $30 \mathrm{~m}(100 \mathrm{ft})$ above sea level. In the bluffs along these rivers, the Pensauken fills broad channels cut deeply into the older Coastal Plain formations. Some of the channels are more than $24 \mathrm{~m}(80 \mathrm{ft})$ thick and are filled largely with cross-stratified, fairly well sorted sand interbedded with thin to thick beds of coarse gravel.

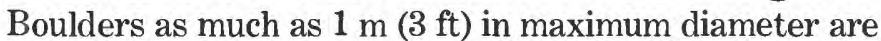
common (fig. 9). These beds typically are light yellow but are irregularly though extensively stained reddish brown or orange-brown by iron oxide. This widespread coloration throughout the unit led some authors to call these sediments the "red gravelly facies" (Rasmussen and Slaughter, 1955; Hansen, 1966).

South to the limit of the unit, the Pensauken continues to fill irregular channels (Hansen, 1966; Weigle, 1970 1 c Salisbury, Md.; Rasmussen and others s to be a fluvia1973 , in southern Delaware) avd'channels as much as 61 tileunit deposited in a $r$ 
$\mathrm{m}(200 \mathrm{ft})$ below sea level. The formation terminates abruptly east of the Salisbury-Rehoboth Beach line. Hansen (1966, fig. 4) thought that the eastward disappearance of the "red gravelly facies" was related to a marine transgression associated with the overlying Beaverdam but that the two units were temporally equivalent, each simply representing different facies of the same rise in sea level. Jordan and others (1967, fig. 4) also considered the Columbia (our Pensauken) and Beaverdam to be related. They thought that both units were fluviatile, the lighter colored Beaverdam being the unweathered downdip equivalent of the Columbia (our Pensauken).

The Pensauken Formation is a fluviatile deposit. Owens and Minard (1978) believe that the Pensauken Formation was deposited as a series of progressively downcutting, eastward-migrating channels. Our data support this interpretation. The Delmarva upland is flanked along the Delaware and Chesapeake Bays by lowlands that have altitudes ranging from 0 to $1.5 \mathrm{~m}$ ( 0 to $5 \mathrm{ft}$ ) above sea level. Drilling in this lowland along the west side of the peninsula did not locate any Pensauken-type sediments, especially from Kent Island southward. In Delaware, on the east side of the peninsula, however, typical reddish-brown sediments occur beneath the lowland as

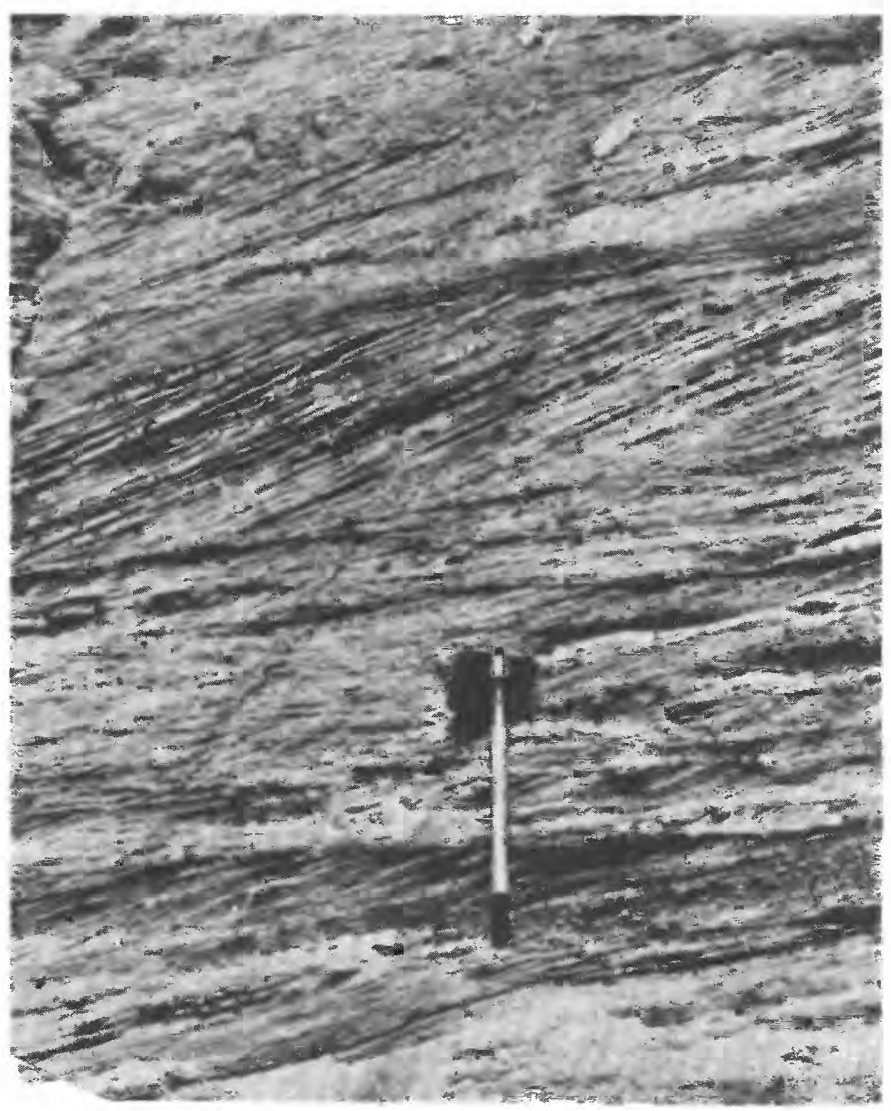

Figure 9.- - eross-o.

Formation. Exposure is Imand and pebble gravel in the Pensa.uken northern Chesapeake Bay. - + the tip of Elk Neck penirasula, far south as Lewes, Del. Therefore, the absence of the Pensauken Formation beneath the western lowland and its presence under the eastern lowland seem to support the eastward migration proposed by Owens and Minard.

No megainvertebrate fossils or trace fossils were found in the Pensauken Formation.

Thin to thick clay-silt beds (orange-brown, green, or, least commonly, dark gray) increase in abundance as the formation is traced southward near Salisbury, Md. Weigle (1972) reported that in the subsurface, the Pensauken has interbedded thin light-colored to black clay. An examination of the pollen in some of this clay revealed a large number of types including those used both as cool temjerature indicators (spruce-fir) and as warm temperature indicators (abundance of oak and hickory) (L. A. Sirkin, written commun., 1973). Such floristic mixtures are common in Tertiary floras rather than in Quaternary floras (Leopold, 1969). The genus Pterocarya and other exctics common in many Tertiary floras were also found in some samples from the Pensauken.

The pollen assemblages suggest a Tertiary age for the Pensauken Formation. Nearly all previous investigators thought these sediments to be Pleistocene (Shattuck, 1901; Miller, 1920; Spoljaric, 1967, to cite but a few), but on the basis of new pollen studies, our interpretation is different. We suggest that all or part of the "Yorktown and Cohansey(?)" Formations is the downdip equivalent of the Pensauken Formation. The Pensauken is the fluviatile facies (figs. 5,6 ) and interfingers with the deltaic and shallow-shelf facies of the "Yorktown and Cohansey(?)." Thus, all are the components of a fluviatile-deltaic-marine sequence like that found in other Coastal Plain formations of Late Cretaceous age, not Pleistocene as formerly supposed.

Linking the fluviatile Pensauken with the deltaic-marine "Yorktown and Cohansey(?)" Formations as part of the same depositional sequence resolves many of the stratigraphic anomalies in the lower peninsula. Specifically, it provides an explanation for the introduction of coarse clasts, including gravel, into a marine environment (represented by the "Yorktown and Cohansey(?)" beds) interpreted to be well out on the Continental Shelf. It also could explain the ample supply of immature sediments (moderately feldspathic beds containing a very immature heavy-mineral suite) and the widespead occurrence of woody fragments in these marine beds.

\section{BEAVERDAM SAND}

The Pensauken ("Pocomoke" and "Manokin") sediments are overlain by light-colored gravelly sand called the Beaverdam Sand by Rasmussen and Slaughter (1955). The formation underlies much of southern Maryland and Delaware but does not extend southward into Cape Charles (fig. 10). The unit is principally white, pale 
green, or pale blue-gray where unweathered and orangebrown like the Pensauken where weathered. For the most part, the depth of weathering in the Beaverdam is only a few feet. Where the depth of weathering is greater, it is difficult to distinguish the Beaverdam from the Pensauken.

The formation is mostly sand, fine to very coarse, locally containing thin beds of gravel. Along the inner (western) edge of its outcrop (fig. 10), particularly between Princess Anne and Pocomoke City, Md., on the south and between Milford and Dover, Del., on the north, the Beaverdam has concentrations of very coarse gravel as much as $0.6 \mathrm{~m}(2 \mathrm{ft})$ in maximum diameter. Thin clay-silt beds, typically pale green or pale gray where unweathered and red or tan-brown where weathered, are very common and seem to be distributed in a random pattern throughout the formation, commonly in- terlayered as crossbeds with sand. At one or two localities, particularly near the Delaware coast, the clay is dark gray and contains large concentrations of peaty material. The sand in the Beaverdam is all cross stratified, typically the tabular type (fig. 11) and less commonly the trough type. The cutbanks of the Beaverdam, even the vertical banks in flooded borrow pits, tend to stand rather than slump because the matrix contains enough clay-silt to bind the sand grains into a semiconsolidated mass.

The Beaverdam Sand is highly feldspathic, in fact, more so than the "Manokin" and "Pocomoke" sands and about the same as the Pensauken. As in the Pensauken, both major types of feldspar are present; microcline is only slightly more abundant than plagioclase (oligoclase predominantly). Heavy-mineral analyses reveal that the Beaverdam in downdip areas has an immature suite

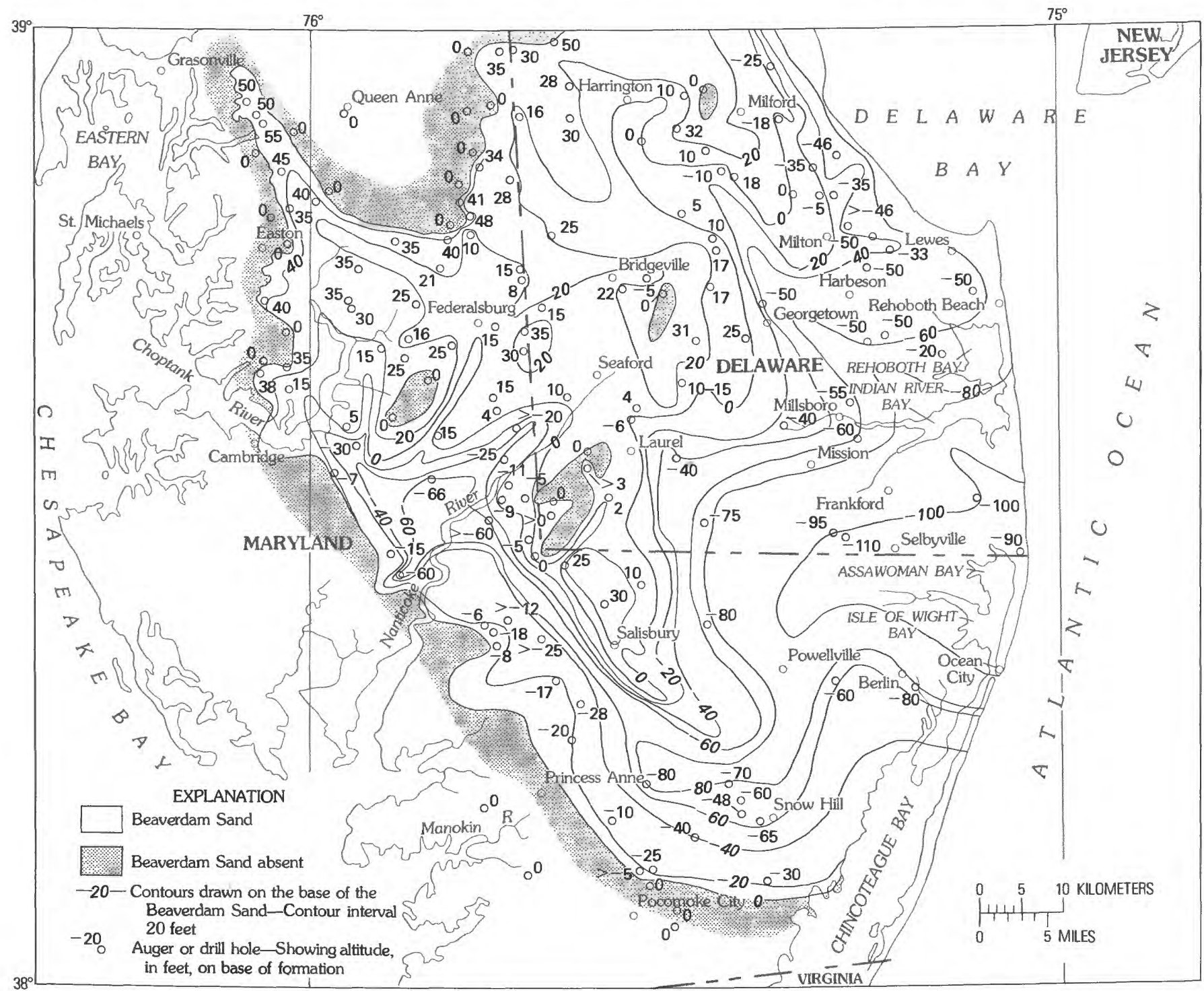

Figure 10.-Map of area underlain by Beaverdam Sand. Contours show form of the base of the formation. 

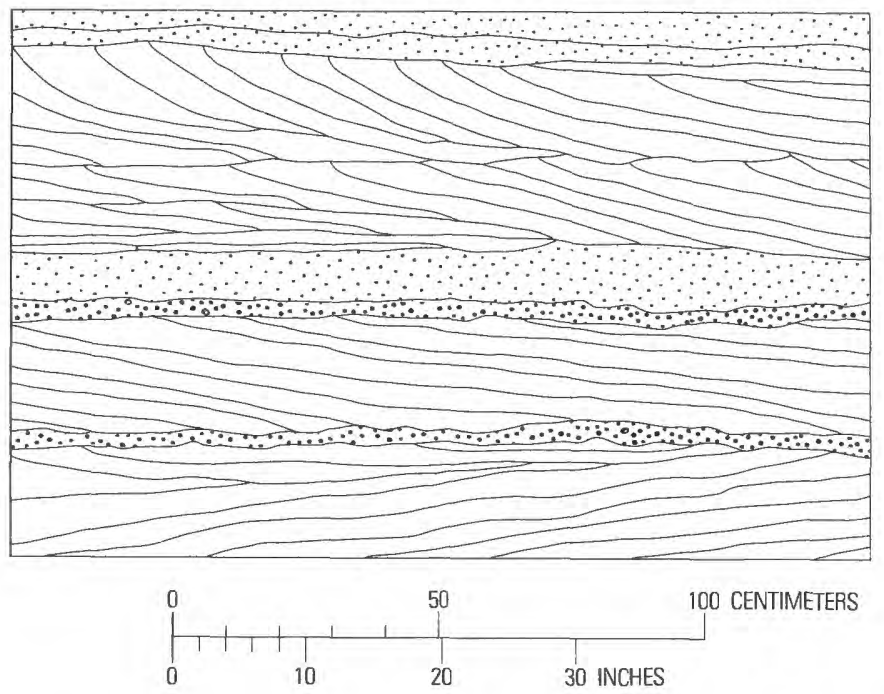

FIGURE 11.-Cross-stratified sand and thin pebble bands in Beaverdam Sand exposed in borrow pit near Berlin (field locality number, Shelbyville 2). Sketched from a photograph.

similar to that observed in the Pensauken and "Manokin" and "Pocomoke" sands. In updip areas, the heavymineral suite is more mature, containing less hornblende than in the Pensauken and the "Manokin" and "Pocomoke" beds. Perhaps in the updip areas, the Beaverdam has reworked and incorporated heavy minerals from the Calvert and Choptank Formations, which have relatively mature heavy-mineral assemblages.

Except for burrows, no invertebrate fossil remains were found in the Beaverdam Sand. In many exposures, abundant long tubular burrows are present that appear to be the result of activity by an unknown organism (fig. 12). However, in exposures of this unit near Berlin, Md., burrows of the shrimp Callianassa were observed.

Near the coast, east of Selbyville, Del. (fig. 5), clay and peat interbedded in Beaverdam Sand are exposed in deep drainage ditches in the wetlands (Selbyville 5). The peat beds contain a rich microflora somewhat different from that found in the Pensauken (L. A. Sirkin, written commun., 1975). The flora is an oak-hickory assemblage. Other warm-climate indicators are black gum and cypress. Exotics such as Peterocarya, Engelhardtia, and podocarp are present. In addition, abundant leaf imprints of the saltmarsh grass Spartina are found. The clay-silt beds in the Beaverdam near Salisbury, Md., the so-called "sea-level clay" discussed by Weigle (1972), contain Pterocarya and a few other exotic pollen types.

The Beaverdam Sand is presumed to be Pliocene on the basis of its microflora. It overlies the Pensauken Formation in the northwest part of the region (fig. 10) and overlies the "Manokin" and "Pocomoke" beds in the area to the southeast. Where the Beaverdam fills chan-
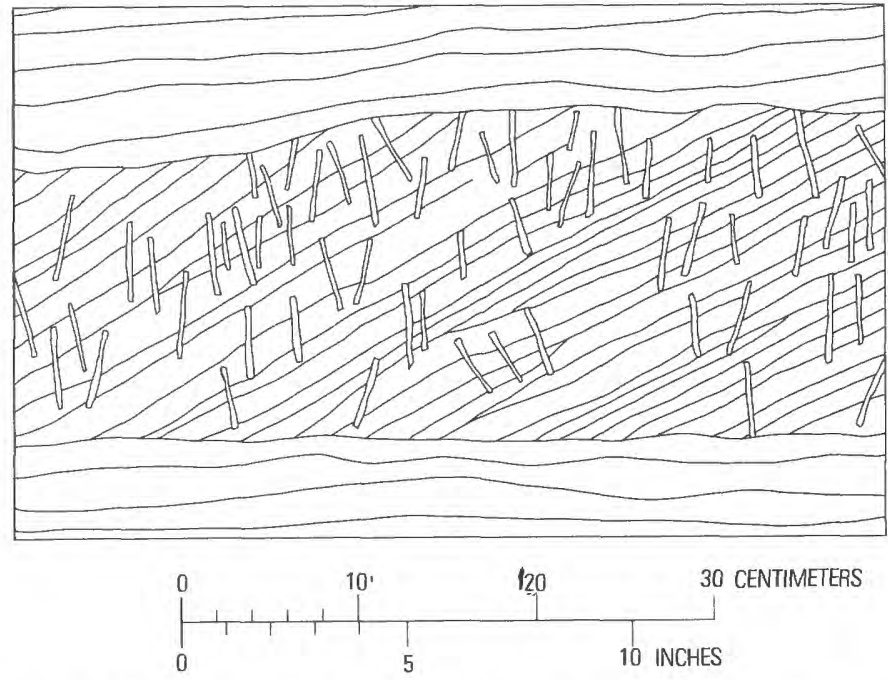

Figure 12.-Tubular borings of the Beaverdam Sand. Small tubes in crossbedded sand exposed in borrow pit near Milford, Del. Sketched from a photograph. Borings are typically $1 \mathrm{~cm}(0.25 \mathrm{in}$.) in diameter and rarely more than $7 \mathrm{~cm}$ ( $3 \mathrm{in}$.) long.

nels eroded through the Pensauken, the unit overlies sediments of the Chesapeake Group. The relationship of the Beaverdam Sand to the Yorktown Formation is still uncertain. In the Pocomoke City area, several formations appear to be present, including the possible Yorktown; the Beaverdam apparently lies unconformably on the Yorktown(?) beds. If this is true, the Beaverdam is post-early to middle Pliocene or late(?) Pliocene in age.

As shown in figure 10, the Beaverdam fills irregular channels cut deeply into the underlying units. In this respect, the Beaverdam has a body geometry similar to that of the underlying Pensauken. The Beaverdam channels, unlike those in the Pensauken, form two large drainage systems, one heading west and northwest (Susquehanna River drainage), the other, north (Delaware River drainage). The maximum thickness of the Beaverdam Sand in the area near Ocean City is more than $30 \mathrm{~m}(100 \mathrm{ft})$.

Our understanding of the depositional environment of the Beaverdam Sand and its relationship to the underlying units is incomplete. The Beaverdam is unconformable on the Pensauken and probably unconformable on the "Manokin" and "Pocomoke" beds and the Yorktown. Hansen (1966) believes that the Beaverdam is an estuarine deposit, but the absence of large amounts of silt and clay common to the present-day estuaries does not favor this interpretation. The channels at the base of the Beaverdam indicate erosion in a fluviatile environment. Widespread ichnofossils in the exposed upper part of the formation suggest deposition in some sort of a marginal marine environment. Thus, the Beaverdam appears to 
represent a late Pliocene regression followed by a transgression.

\section{WALSTON SILT}

The highest part of the central Delmarva Peninsula is underlain by a deeply weathered sequence of interbedded silt, clay, and sand of variable thickness, which Rasmussen and Slaughter (1955) named the Walston Silt (fig. 5). The unit is believed to be marine and occurs at altitudes of nearly $21 \mathrm{~m}$ (70 ft) above sea level. This is the highest altitude of a marine unit in the central Delmarva Peninsula.

The Walston Silt that underlies only a small area near Salisbury, Md. (fig. 13), is exposed in borrow pits near Salisbury and in roadcuts west of Powellville (fig. 14). The Walston here is predominantly thick, massive to thinly laminated clayey silt interbedded with thin, lightcolored, poorly sorted medium sand and locally scattered pieces of gravel (weathered white chert) as much as 3 inches in diameter, generally near the base of the unit. The clayey silt is varicolored-dark brown, pale gray, or pale green. Red iron oxide is commonly formed along cracks in these clayey strata, mostly in beds near the surface, suggesting subaerial oxidation.

The type locality of the Walston, as defined by Rasmussen and Slaughter (1955), was in a drill hole (well WiCg-40, not shown in fig. 13) near Walston Switch Road, northeast of Salisbury, Md. As recorded by these authors and confirmed by us in a few drill holes about 3.2 $\mathrm{km}$ (2 miles) southeast of their locality, the predominant lithology in the Walston is clay-silt, mostly weathered to varying degrees in the upper part of the formation, and a less weathered dark-gray or rarely very peaty clayey-

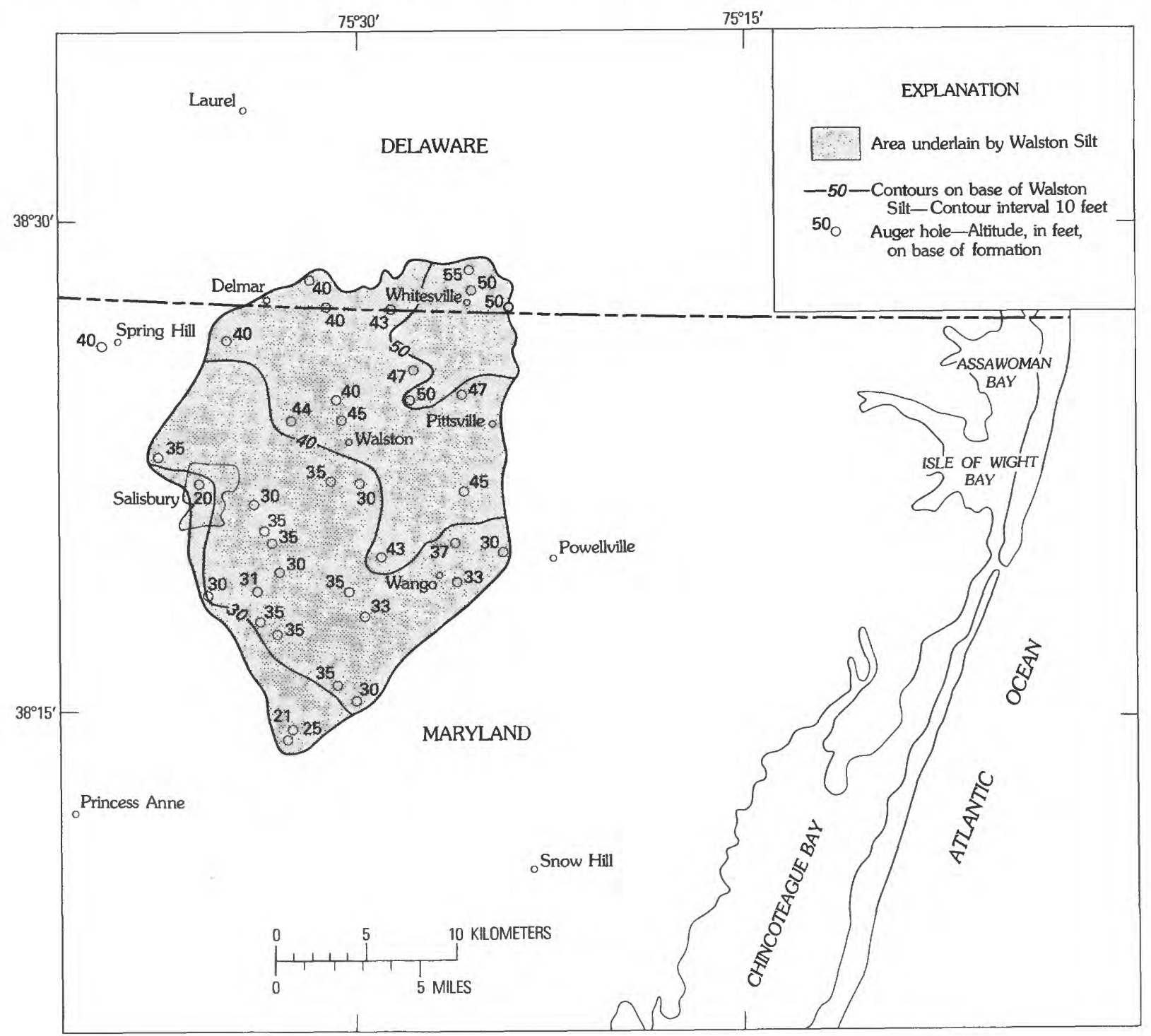

FIGURE 13.-Map of area underlain by the Walston Silt. Contours show form of the base of the formation. 


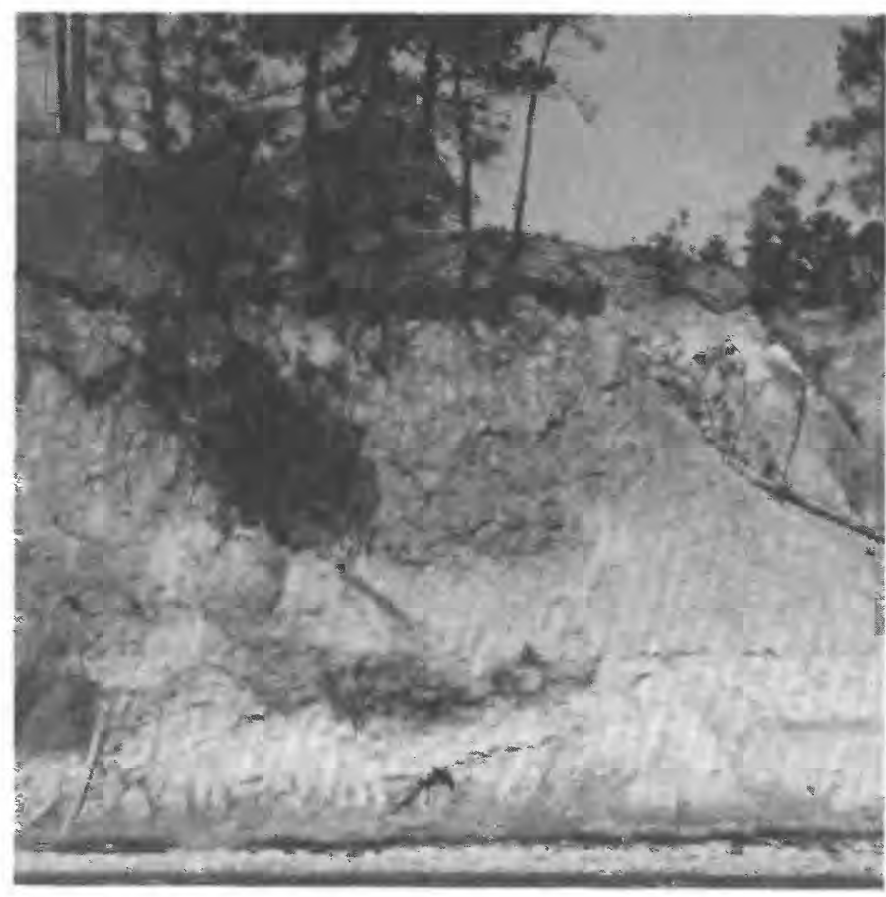

Figure 14.-Walston Silt near Powellville, Md. Varicolored, thick, massive to thinly laminated clayey silt and poorly sorted sand. Exposure in roadcut along State Route 350 about $1.6 \mathrm{~km}$ (1 mile) west of Powellville.

silt in the base of the formation. Figure 15 shows the lithologies found in this part of the formation.

Petrologic studies were conducted, mostly on the claysilt strata of the Walston Silt. The clay-mineral assemblage is unusual when compared with that of the older underlying formations. The clay minerals are dominated by a disordered kaolinite, which is present even in the unweathered dark-gray clay beds at the base of the unit. We conclude, therefore, that the disordered kaolinite is a detrital rather than a secondary mineral in this formation. Halloysite and gibbsite, however, are found in the upper weathered strata, suggesting that some postdepositional alteration of the clay minerals in the formation has taken place.

Because of the clayey nature of much of this unit, heavy-mineral concentrates were difficult to obtain. Where found, the heavy minerals in the upper weathered clay-silt and loose sand are characterized by a mature suite (high ilmenite, zircon, tourmaline, and rutile). The heavy-mineral assemblage in the basal unweathered beds is less mature, containing small amounts of epidote and hornblende. This mineral assemblage, however, is much more mature than that in the underlying Beaverdam.

The base of the Walston Silt has a general regional slope to the southwest (fig. 13). The basal contact with the Beaverdam, exposed at a few locations, consists of

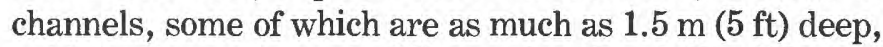
cut into the upper part of Beaverdam Sand. The Walston

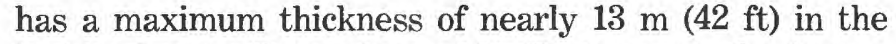
highlands near Parsonburg, Md. To the east, the formation is terminated along, and lies atop, a low dissected north-trending scarp extending from Pittsville to near Powellville, Md. (fig. 13). To the west, the Wicomico River and its tributaries have eroded deeply into and have locally removed much of the Walston. Erosional remnants detached from the main mass of the formation are scattered along the western side of the outcrop belt. Such a hill of clay-silt at the old Spring Hill Airport 1.9 $\mathrm{km}$ (1.5 miles) northeast of Hebron, Md., is the largest such outlier. To the south, the Walston is truncated and buried beneath younger Pleistocene deposits.

No invertebrate fossils were found in the Walston Silt. Ichnofossils, however, small rodlike borings similar to those found in the Beaverdam, are common in the exposures of the lower sandy beds near Powellville, Md. Studies of the pollen (L. A. Sirkin, written commun., 1975) from the basal peaty beds revealed a warm flora characterized, as in the underlying formations, by a large number of species, including small amounts of exotics such as Pterocarya. Such a microfloral assemblage, as noted earlier, is typical of the underlying Tertiary beds, and the Walston, on this basis, is also probably Tertiary in age.

The Walston Silt is interpreted to be a barrier-backbarrier sequence not unlike that described by Kraft and others (Kraft, 1968, 1971; Kraft and others, 1973) in the Holocene deposits of coastal Delaware. The Walston is the oldest recognizable barrier-back-barrier sequence in the Delmarva Peninsula, recording a high stand of the sea that reached to about $21 \mathrm{~m}(70 \mathrm{ft})$ above present sea level. This high stand is probably Tertiary, not Pleistocene. The depth of weathering in the Walston suggests that the unit is old. Precisely what part of the Tertiary the unit represents could not be established but, on the basis of stratigraphic position, it is probably late Pliocene.

The general slope of the base of the Walston Silt (fig. 13) is to the southwest in the general direction of the area underlain by the Yorktown Formation in the Virginia part of the Delmarva Peninsula. It may be that the Walston is a barrier-back-barrier facies of the Yorktown, which is largely a shelf deposit or a regressive facies of the Beaverdam Sand. We would favor the latter interpretation.

\section{OMAR FORMATION}

A large ribbon-shaped mass of interbedded clay-silt and sand parallels the east coast of the lower Delmarva Peninsula from Delaware south into Virginia and northwest along the east side of Chesapeake Bay as far north as the Nanticoke River (fig. 5). We herein adopt this sin- 
A

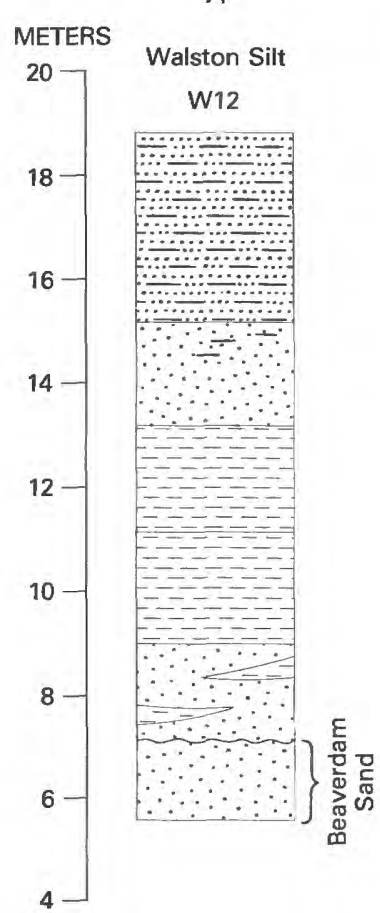

EXPLANATION

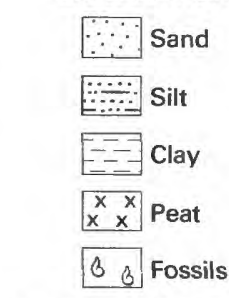

$B$, Berlin quadrangle

$\mathrm{G}$, Girdletree quadrangle

W, Wango quadrangle
$B$

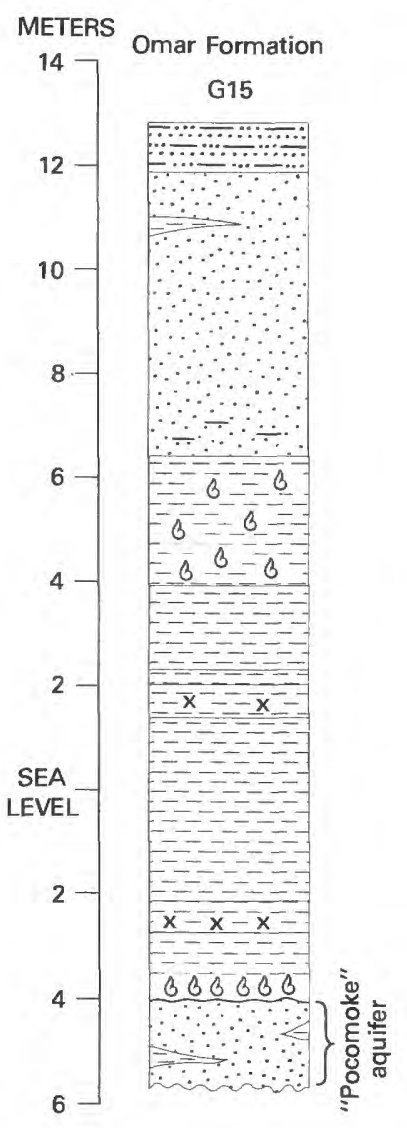

$c$

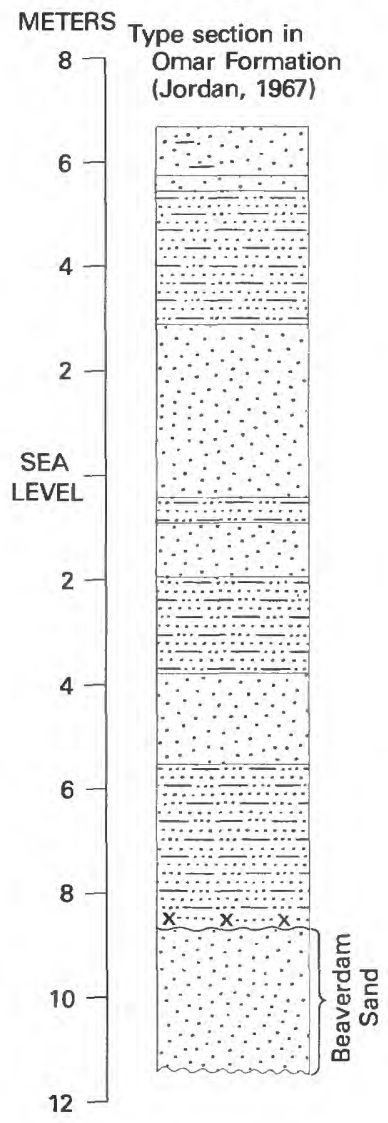

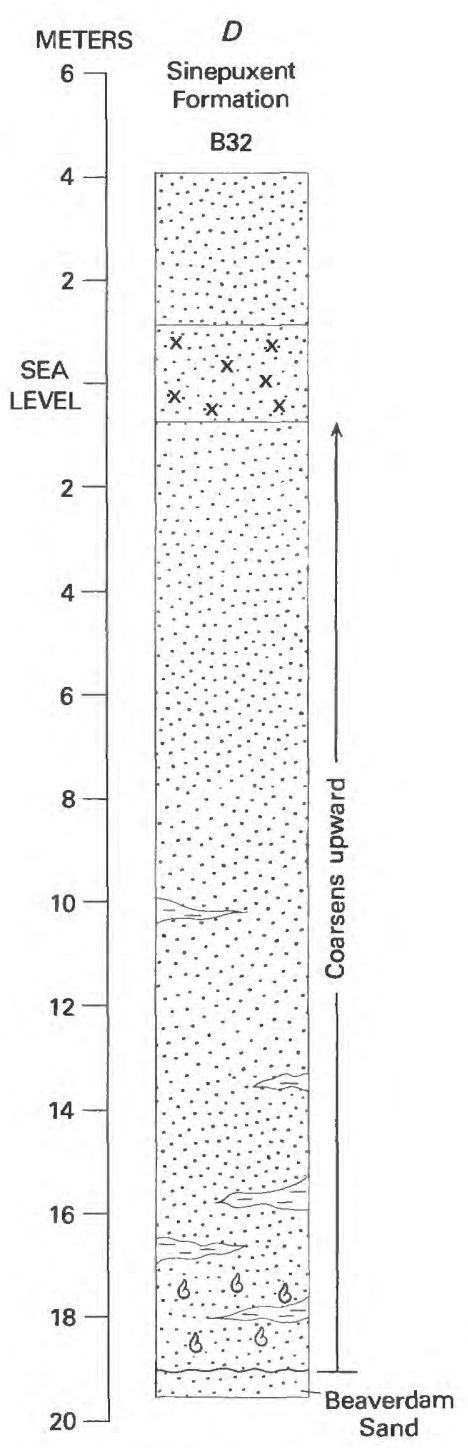

Figure 15.-Columnar sections of the Sinepuxent and Omar Formations and Walston Silt. Lithology based on samples from auger or drill holes.

uous body as the Omar Formation of Jordan (1962) and Jordan and others (1967), named for the Omar trough in southern Delaware (fig. 16); these beds were described in an area near Omar (fig. 4B). The Omar extends southwestward into Virginia to another small basin or trough, the Accomac trough, named for Accomac, Va. (R. B. Mixon, written commun., 1974). In these two troughs or basins, the Omar reaches its maximum thickness. We do not, however, agree with Jordan and others' interpretation as to the origin and distribution of this unit.

The formation consists primarily of an updip light-colored sand facies and a downdip largely dark-colored claysilt facies which is interstratified with thinner beds of light-colored sand, especially to the south in the Accomac trough. In parts of Delaware and Chesapeake Bays, the Omar trough and its southern equivalent, the Accomac, are overlapped by younger Quaternary beds called the
Kent Island Formation. At its type locality, in northern Chesapeake Bay, the Kent Island is lithically distinct from the underlying Chesapeake Group. The same situation exists in the middle Delaware Bay region of the peninsula. However, the Kent Island Formation overlaps the lithically similar Omar beds in the lower part of the Delaware Bay region and overlaps the beds of the Accomac trough in the lower part of the Chesapeake Bay region. Part of the mapping program required contouring the base of the Quaternary. Thus, where the Kent Island overlaps the Omar (including beds of the Accomac trough), this basal Quaternary surface was outlined in drill holes. Distinguishing between the Kent Island beds and Omar beds lithologically was not possible. In many holes, therefore, the two units were lumped into a single lithic unit called the Omar and Kent Island Formations, undivided, in the subsurface of this region. 


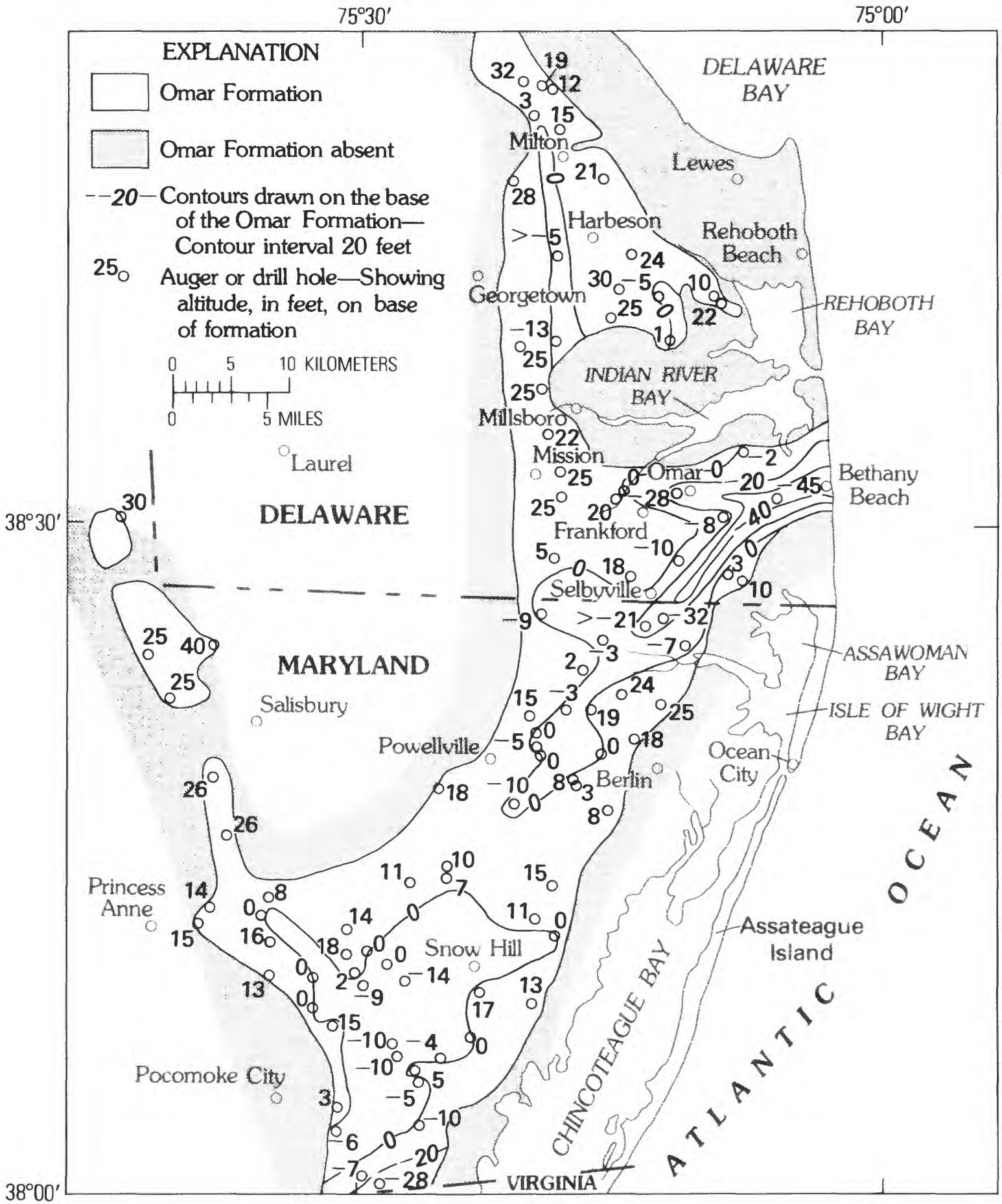

FIGURE 16.-Map of area underlain by the Omar Formation in southern Delaware and Maryland. Contours show form of the base of the formation.

The dominant lithology, the dark facies, forms clay plugs as much as $15 \mathrm{~m}(50 \mathrm{ft})$ thick in the two aforementioned troughs or basins. As shown in both areas (fig. 15), this lithofacies consists of thick beds of sand and clay-silt. Some thin peaty beds are also present, typically near the base of each unit. In many places, clay-silt beds underlie broad flat areas where altitudes at the top of this lithofacies are as much as $11 \mathrm{~m}(35 \mathrm{ft}$ ) above sea level. In many respects, the sequence of peaty beds overlain by clay-silt and interbedded sand is similar to that found in the Walston Silt (fig. 15). In both the northern and southern troughs, however, calcareous fossils are common throughout the Omar, in contrast to the nonfossiliferous character of the Walston beds. Typically, the 
fossils are in discrete beds rather than being dispersed throughout the units. In the southern or Accomac trough, thick beds of light-colored sand are more common interstratified with the dark facies and have the characteristic bedding associated with beach and barrier-bar deposits (R. B. Mixon, written commun., 1974).

Sand is also widespread in a broad plain, updip from the interbedded clay-silt-sand facies, at altitudes as much as $17 \mathrm{~m}$ (55 ft) above sea level. The age (or ages) of this updip sand is in many places indeterminate because the stratigraphic relationships within the sand plain are largely unknown. The sand apparently has been reworked postdepositionally by aeolian and fluvial processes during the late Wisconsin (Denny and others, 1978). Thus, the precise extent and, more importantly, the highest altitude reached by the Omar sand cannot be established.

A loose, light-colored sand, which Rasmussen and Slaughter (1955) called the Parsonsburg Sand, commonly overlies both the Omar and the Walston. The sand locally fills depressions between the clay-silt facies of the Walston (fig. $4 A$ ). This sand was extensively drilled in the uplands near Parsonsburg and in many places has peaty sediment at the base. Radiocarbon dating of the sediments that are rich in organic matter indicates that most are late Wisconsin in age (Denny and others, 1978). Denny and others have ascribed a fluviatile-eolian origin to these upper Wisconsin beds.

The lithology and distribution of the Parsonsburg suggest a nearby source, probably sandy beds in the Omar or the Walston. The source beds are believed to have been reworked, probably on a beach or associated dune field, during a Sangamon high stand of the sea about 12 $\mathrm{m}(40 \mathrm{ft})$, perhaps as much as $17 \mathrm{~m}(55 \mathrm{ft})$, above present sea level. At a few localities, the Parsonsburg Sand consists of horizontally bedded, extensively burrowed sand suggestive of a beach environment (fig. 17). The scarcity of outcrops and of subsurface data makes it difficult to distinguish sandy beach deposits from sandy eolian or fluvial deposits and to determine whether the sandy deposits are of Pliocene or of late Wisconsin age.

The northern or Omar trough containing the dark claysilt facies has been traced as far north as Bethany Beach, Del., where the trough is lost beneath the sea. The deepest known part of the Omar trough is at Bethany Beach. To the north, the extent of the Omar Formation is concealed beneath Indian River Bay. Farther north, the Omar was traced in the subsurface to the Delaware Bay area near Milton, Del. Between Milton and Milford, the outcrop belt of the Omar narrows. As to the south, the formation is in troughs or in channels (fig. 20). A major north-trending channel system passes through Harbeson to slightly beyond Milton, Del. The Omar Formation north of Indian River Bay is more sandy than it is to the

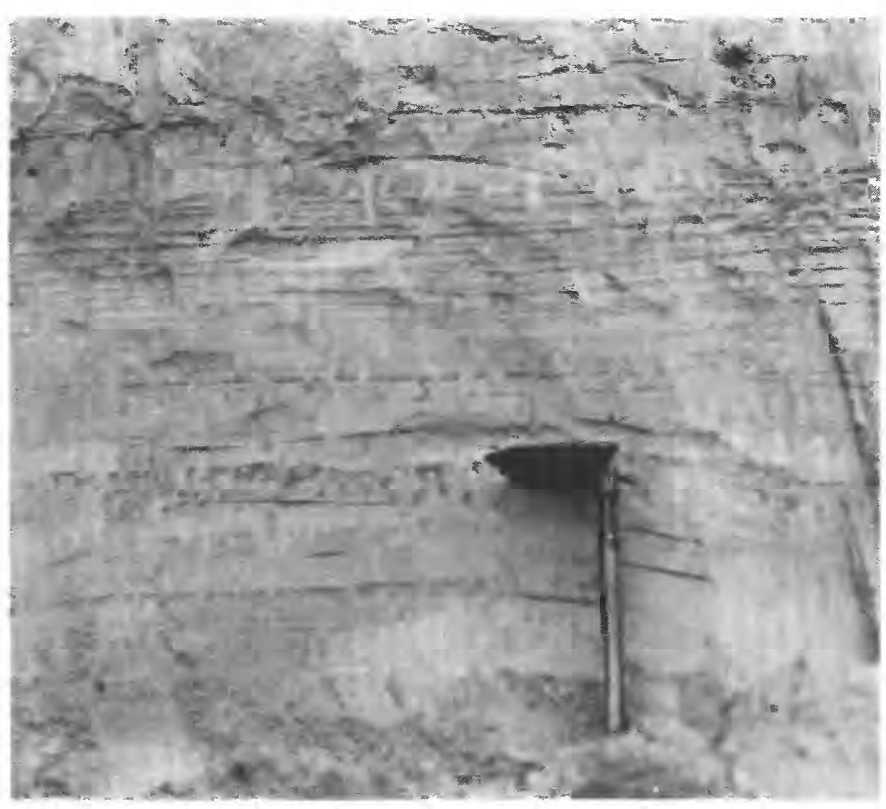

FIGURE 17.-Horizontally bedded sand, extensively burrowed, suggestive of a beach environment. This sand possibly is in the Omar Formation. Exposure in borrow pit near Pittsville, Md., altitude about $17 \mathrm{~m}(55 \mathrm{ft})$ above sea level.

south. Fossils, which were so common on the clay-silt facies south of the Indian River valley, were not found in the northern area, even though a large number of holes were augered into the formation in this area.

Petrologic examination of the clay-sized clasts in the formation indicates much variability. In general, kaolinite, montmorillonite, and illite are present in all samples from both troughs. Chlorite is much more abundant in the southern trough. Kaolinite in the Omar is well ordered rather than being disordered as in the Walston. Heavy-mineral assemblages are variable along the outcrop belt but, on the average, are the most immature assemblages in any unit discussed thus far. Hornblende, epidote, and garnet are very abundant in the nonopaque heavy-mineral fractions. Pyroxene, both augite and hypersthene, make first appearance in beds of the Omar and Accomac troughs in the lower Delmarva Peninsula.

As mentioned earlier, fossils are very common throughout the unit. The assemblages vary, reflecting in large part the salinity of the depositional environment in which the faunas lived. In the northern or Omar trough, the bulk of the fauna is the restricted type dominated by Crassostrea virginica, a dominantly low-salinity form. In the southern orAccomac trough, the faunas reflect more open marine conditions, as evidened by the more salinetolerant Ensis, Noetia, Spisula, and Merceneria.

The microflora in the Omar Formation is dominated by an oak-pine-hickory assemblage indicating that a warm- 
temperate climate (L. A. Sirkin, written commun., 1974) prevailed during much of the time when this formation was deposited. Pollen of such trees as spruce and hemlock, normally cool-temperature indicators, was found in a few samples, mostly from the base of the clay-silt facies. The interlayering of microflora indicative of both warm and cool temperatures suggests varying climatic conditions during the depositional history of the formation.

All the macrofossils, microfossils, and microflora found in the Omar Formation are living species today and therefore cannot be used to date this unit specifically. A specimen of Merceneria merceneria from Accomac, Va., was dated by the uranium disequilibrium series method. Ages ranging from 90,000 to 126,000 years were obtained, the average being near 106,000 years (B. Szabo, written commun., 1974), suggesting a Sangamon age. Samples of the oyster Crassostrea virginica were collected from the bank of Pepper Creek near Frankford, Del., and were dated by the same method. Shells of this type, which are almost wholly calcite and which frequently yield anomalous ages, were, in this particular case, dated at $107,000 \pm 10,000$ years, or essentially the same age as the Merceneria from Accomac, Va. A suite of fossils in beds thought by us to be the equivalent of the Omar Formation were collected on the west side of Chesapeake Bay from the famous fossil-collecting locality at Wailes Bluff, Md. Three different types of shells were dated: the oyster (Crassostrea virginica), two pelecypods (Merceneria campechiensis and Merceneria merceneria), and a gastropod (Busycon canaliculatum). The oyster yielded an age of $112,000 \pm 14,000$; the two pelecypods, 104,000 to $107,000 \pm 10,000$ years, and the gastropod, $84,000 \pm 9,000$ years. Thus, as in the shells from the Delmarva Peninsula, the oyster and pelecypod yielded nearly the same age. The gastropod, the only one dated here, or possibly, for that matter, anywhere else in this region, yielded a decidedly younger age; hence, it is considered anomalous. It should be noted, however, that although concordance is good between the ages given by the two shell types found in the Omar Formation, this was not the situation in the Norfolk Formation near Norfolk, Va. An oyster from the Norfolk gave an age that was nearly twice as old as that of a pelecypod from the same unit (about 111,000 vs. about 62,000 years, respectively (B. Szabo, written commun. 1974).

The Omar Formation, as we have suggested, appears to have been deposited in several coastal environments during a Sangamon transgression-open shelf, barrierback barrier, and open bay.

Perhaps the greatest significance of the Omar Formation in our study is that it represents the maximum height reached by the Quaternary seas, certainly the Sangamon seas, in this part of the Atlantic coast.

\section{IRONSHIRE FORMATION}

A narrow and discontinuous band of sand and gravelly sand lies against and slightly east of a prominent eastfacing scarp that parallels the Atlantic coast from Rehoboth Beach, Del., to the southern tip of the Delmarva Peninsula in Virginia (fig. 5). Large parts of this sand belt and the adjacent scarp have been eroded away, particularly south of Chincoteague, Va., and, to a lesser extent, in the Rehoboth Bay region in Delaware. Along the scarp, the sand lies unconformably on the Beaverdam Sand or the Omar Formation. The sand is well exposed in borrow pits in the vicinity of Ironshire, Md.; this area has been selected as the type locality of the formation. Here, the Ironshire Formation has an upper surface elevation nearly $9 \mathrm{~m}(30 \mathrm{ft})$ above sea level. The maximum thickness of the formation is about $7.6 \mathrm{~m}(25 \mathrm{ft})$.

The lower $2-3 \mathrm{~m}(8-10 \mathrm{ft})$ consists of loose pale-yellow to white well-sorted medium sand. Lower sand is characterized by long, low-angle inclined beds (fig. 18). Layers of black minerals, locally disrupted by small cylindrical borings, are common in lower beds.

The upper beds also consist of light-colored sand. This sand, however, is less well sorted and coarser; gravel is a common constituent. The sand is extensively cross stratified, trough cross-stratification being the most common type (fig. 19). The scale of cross strata ranges from a few inches to several feet. Trace fossils are not common in these beds; in a few places, well-developed Callianassa borings were observed. Along the inner

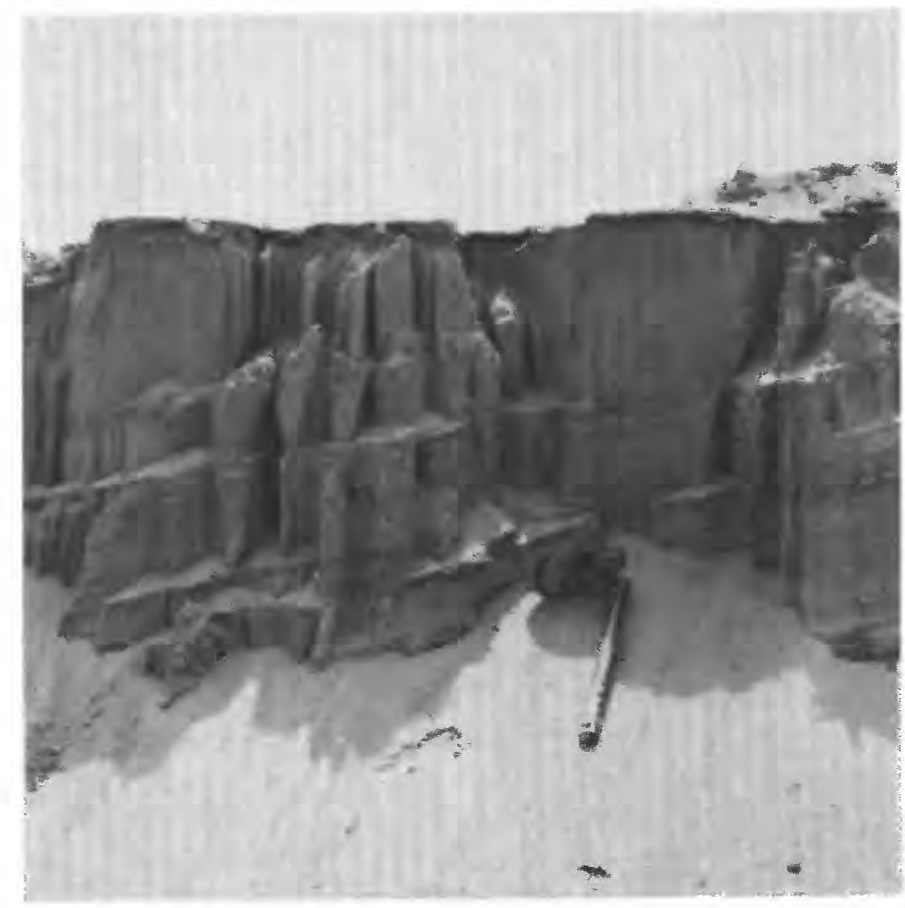

FIGURE 18. - Gently inclined beds in lower part of the Ironshire Formation. Exposure in borrow pit near Berlin, Md. 


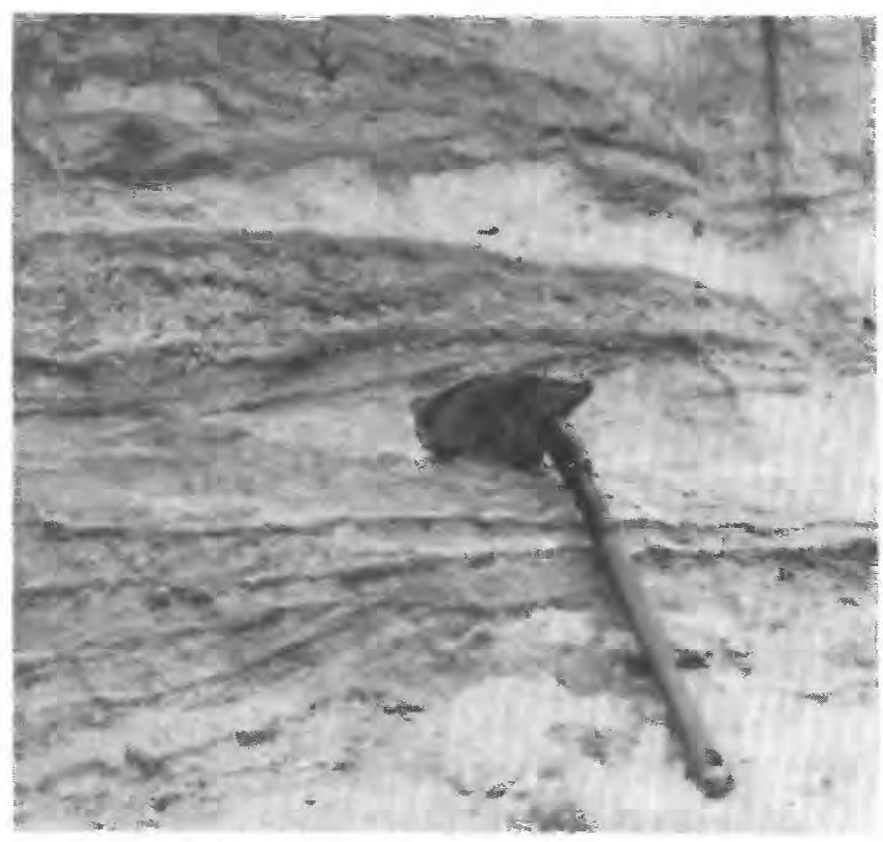

FIGURE 19.-Cross-stratified sand and gravel of the upper part of the Ironshire Formation. Exposure in borrow pit near Berlin, Md. edge of the sand belt, the basal beds locally contain coarse gravel individual clasts as much as $12.7 \mathrm{~m}$ (5 in.), in diameter. In the type area, the basal contact with the underlying formation, the Beaverdam Sand, is sharp.

North of Ironshire, one of the largest remnants of the Ironshire Formation is at Rehoboth Beach where the sand beds are exposed along the Lewes-Rehoboth canal. Most of the minor sedimentary features that were seen at Berlin were also observed at the Lewes-Rehoboth Canal, including particularly well developed Callianassa burrows. The light-colored sand was traced, mainly by drilling, up Delaware Bay to the northwest, to the northern limit of our study area. This sand is separated from the older formations of the central Delmarva Peninsula by an intermittent scarp having a toe nearly $6 \mathrm{~m}(20 \mathrm{ft})$ above sea level, or essentially the same level as the scarp toe near Berlin, Md. This relationship is shown in a cross section across the lowland bordering Delaware Bay (fig. 20). As shown in this section, the light-colored sand overlies channels cut into the Beaverdam Sand. The deepest channel found extends $27 \mathrm{~m}(90 \mathrm{ft})$ below sea level (not shown in fig. 20). The maximum thickness of the Ironshire Formation is about $33 \mathrm{~m}$ (110 ft) but normally averages about $10 \mathrm{~m}(30 \mathrm{ft})$.

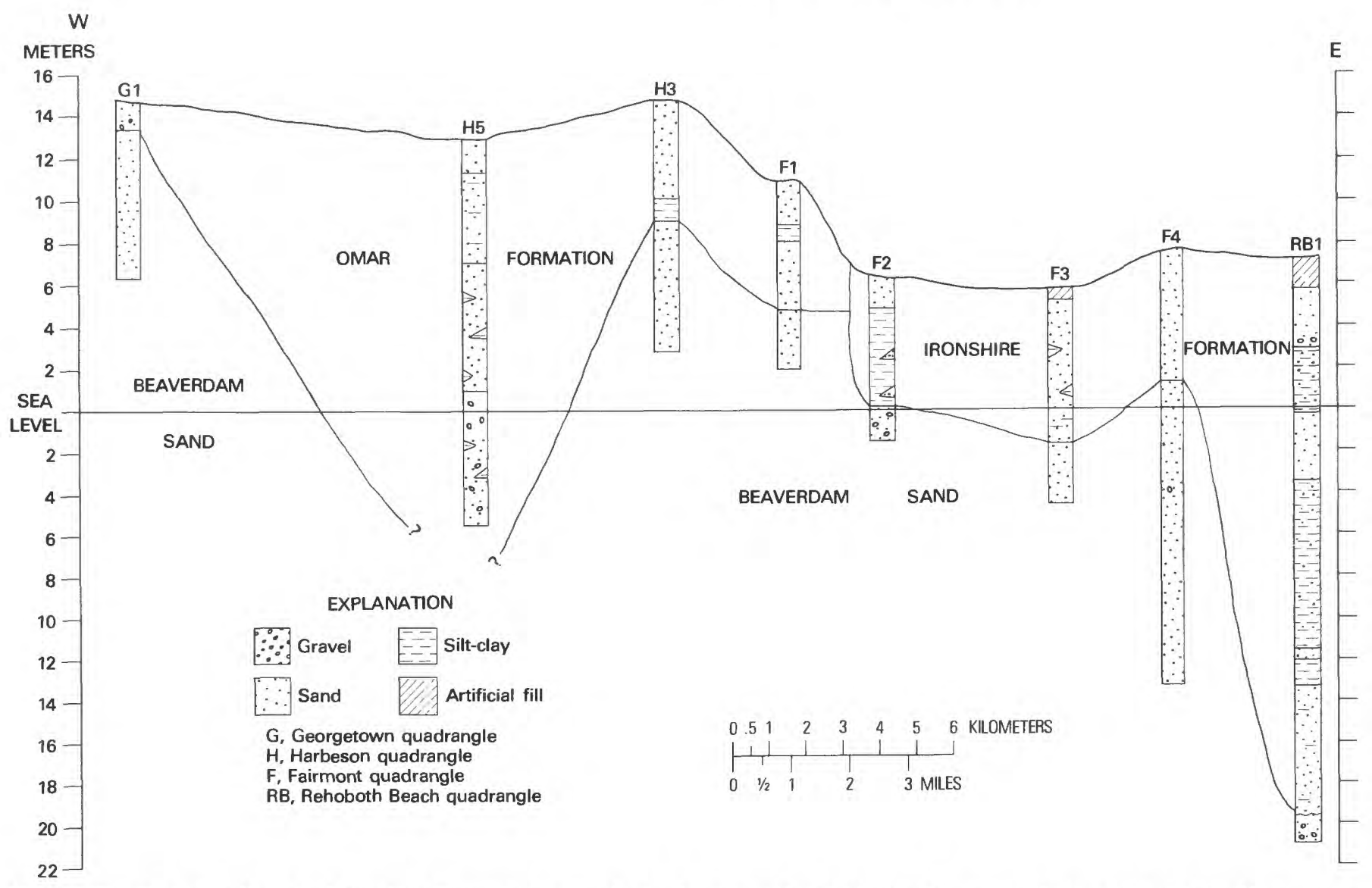

FIGURE 20.-Section of Omar and Ironshire Formations across lowland on east side of Delmarva Peninsula. Section extends from Georgetown, Del., on west to Rehoboth Beach, Del., on east. 
The channel fill typically is less well sorted than the upper light-colored sand. A wide variety of textural types is present in the channels-clayey sand, silty sand, sandy silt, and gravelly sand. Thin beds of peat are also present locally. In addition to the poorer sorting, the channel sediments also have varying amounts of finely dispersed carbonaceous matter, which colors these sediments varying shades of gray. These dark beds are considered to be the estuarine-fluviatile facies of the Ironshire Formation.

Compositionally, the dark channel clasts are more mature than the clasts in the overlying beach sands. The channel clasts have a moderate amount of feldspar and heavy-mineral assemblages characterized by low amphibole and pyroxene content. The light-colored beach sand has, in contrast, higher concentrations of feldspar and heavy-mineral assemblages characterized by a high concentration of amphibole and higher than average concentrations of pyroxene. The channel clasts seem in large part to have been locally derived from older formations, whereas the upper sands are fresher sediments derived from the crystalline sources to the north. The clay-mineral assemblages from the channels typically contain all the clay-mineral types-kaolinite, illite, montmorill onite, and chlorite. The low chlorite content also could be interpreted as an indication of a local source for the sediments in the channels.

The age of the Ironshire Formation is conjectural. The invertebrate fauna (Spisula sp. and possible Merceneria sp.) are too long-ranging species to be of specific use in determining the age of this formation. Microfloral assemblages from the dark beds also were nonspecific in determining the age of the unit. The microflora, however, is characterized by pine, oak, and hickory. Such an assemblage, indicative of a warm climate, is generally interpreted to indicate an interglacial age. The Ironshire rests on the Omar, which is also considered to be Sangamon in age. If the Ironshire is an interglacial deposit, as indicated by the microflora, then it also is probably Sangamon in age, but it represents a regressive-transgressive cycle distinct from the Omar and not a simple stillstand after the Omar high stand of the sea. Regional correlations in the Delaware River valley suggest the presence of two Sangamon units (Owens and Minard, 1975, and 1978). The Ironshire is correlated with the younger Sangamon unit called the "beds at Van Sciver Lake." This informal unit includes the Cape May Formation of other investigators. The Cape May Formation has yielded an age of greater than 40,000 years (Richards and others, $1965)$ and a microflora indicative of a warm climate (L. A. Sirkin, written commun., 1975).

The Ironshire Formation appears to represent a cycle of erosion and deposition separate from that of the Omar. After deposition of the Omar, sea level fell, and the deep channels near Rehoboth Beach were cut. Sea level then rose again, and the channels were filled with fluviatileestuarine sediment. The final phase was the deposition of the upper beach sands which encroach on and against the eroded edges of the older formations of the peninsula.

\section{SINEPUXENT FORMATION}

A lowland lies seaward of the prominent east-facing scarp present along much of the Maryland coast. The widest part of the lowland is Sinepuxent Neck, a peninsula between Berlin and Ocean City, Md. (fig. 5). There are no exposures in the lowland, but drill holes indicate that Sinepuxent Neck is underlain by dark, poorly sorted, silty fine to medium sand (fig. 15D), for which we propose the name the Sinepuxent Formation, herein adopt it, and designate Sinepuxent Neck the type locality. The sand in the lower part of the unit is fine grained and contains thin beds of black clay. In all drill holes into the formation the sand coarsens upward. Throughout Sinepuxent Neck, the upper part of the formation consists of a thin, loose, light-colored well-sorted sand that overlies a brown peat to peaty sand. The persistence of these peaty beds throughout this region and in the subsurface beneath Assateague Island suggests that they are part of the Sinepuxent Formation, rather than a separate unit.

The sand of the Sinepuxent is lithically distinct from all other units discussed earlier. This sand consists largely of quartz, feldspar, and mica (varying mixtures of muscovite, biotite, and chlorite). The abundance of the micaceous minerals distinguishes the Sinepuxent from the older formations of the lower Delmarva Peninsula. Heavy minerals in the Sinepuxent are abundant and invariably constitute a full suite (amphibole and pyroxene abundant). The clay suite in the Sinepuxent has all the major clay minerals (kaolinite, montmorillonite, illite, and chlorite).

The Sinepuxent Formation has been traced from Bethany Beach, Del., southward beneath the coastal lowlands to the Maryland-Virginia boundary (fig. 5). Southward to the tip of the Delmarva Peninsula, erosion during the Holocene has cut deeply westward into the central peninsular upland, and deposits referrable to the Sinepuxent have been recognized at only few localities in this region (R. B. Mixon, written commun., 1975).

The relief on the surface of the Sinepuxent Formation is very low. Altitudes in this lowland range mostly from 0 to $5 \mathrm{~m}$ ( 0 to $15 \mathrm{ft}$ ) above sea level and may reach as high as $6 \mathrm{~m}(20 \mathrm{ft})$ in a few areas. South of Public Landing, Md., and adjacent to the scarp, a series of low (as much as $6 \mathrm{~m}$ (20 ft above sea level) ridges (ridge and swale topography) appear to be part of the Sinepuxent Formation. Similar ridge-and-swale topography at this altitude were also observed at a few localities east of the 
main scarp, particularly near the southern tip of Delmarva Peninsula (R. B. Mixon, written commun., 1975).

The age of the Sinepuxent could not be determined from the fossils present because all forms found in this unit are alive today. Radiocarbon age determinations on some of the samples of the peat near the top of the unit yielded some ages near $31,000 \pm 1,000$ years B.P. (U.S. Geol. Survey Radiocarbon Lab-Sample W-2610). Others were older than upper limit for the method $(34,000$ years, W-2730) although considerable radiocarbon activity was detected in these samples. Shells from beneath the peat at Assateague Island gave an age of $28,750 \pm 1,100$ radiocarbon years ( $\mathrm{W}-2845)$, but shells typically give less reliable ages than woody materials; nonetheless, the near 30,000-year-old figure for the shells is in fair agreement with the ages determined on wood. It suggests, therefore, that the Sinepuxent is middle to late Wisconsin in age.

We suggest that the Sinepuxent Formation is a marginal marine unit deposited in the middle Wisconsin. To establish the precise altitude to which sea level rose during this time is difficult because of the absence of any recognizable barrier facies associated with this formation. If the top of the dark-gray micaceous sand is used as a datum, sea level during this period was probably at least $1.5 \mathrm{~m}(5 \mathrm{ft})$ above the present level. Therefore, the
Sinepuxent Formation suggests a high-level stand of the sea during middle Wisconsin time.

Fossils are common in the Sinepuxent Formation, particularly in the basal clayey beds. The faunal assemblage has modern aspects and is characteristics of a bay or open sound (J. E. Hazel and B. W. Blackwelder, written commun., 1971); Tagelus and Gemma are abundant and are diagnostic fossils of such a depositional environment.

Pollen-rich strata are common in the Sinepuxent. The pollen assemblages, characterized by pine-spruce and birch, do not vary significantly throughout the formation (L. A. Sirkin, written commun., 1974). Such an assemblage is interpreted as indicating a cool-temperate climate.

The Sinepuxent Formation represents a major transgressive event. From north to south it rests unconformably on the Omar Formation from Bethany to Public Landing, Md., and on the "Yorktown(?) and Cohansey(?)" Formations from Public Landing to the Maryland-Virginia boundary (fig. 5). Interestingly enough, the Sinepuxent at no point was found to overlie the Ironshire Formation. The fact that the base of the Sinepuxent is well below that of the Ironshire suggests that the latter unit was removed prior to the deposition of the Sinepuxent, as illustrated in figure 21. This relationship was confirmed at several localities along the con-

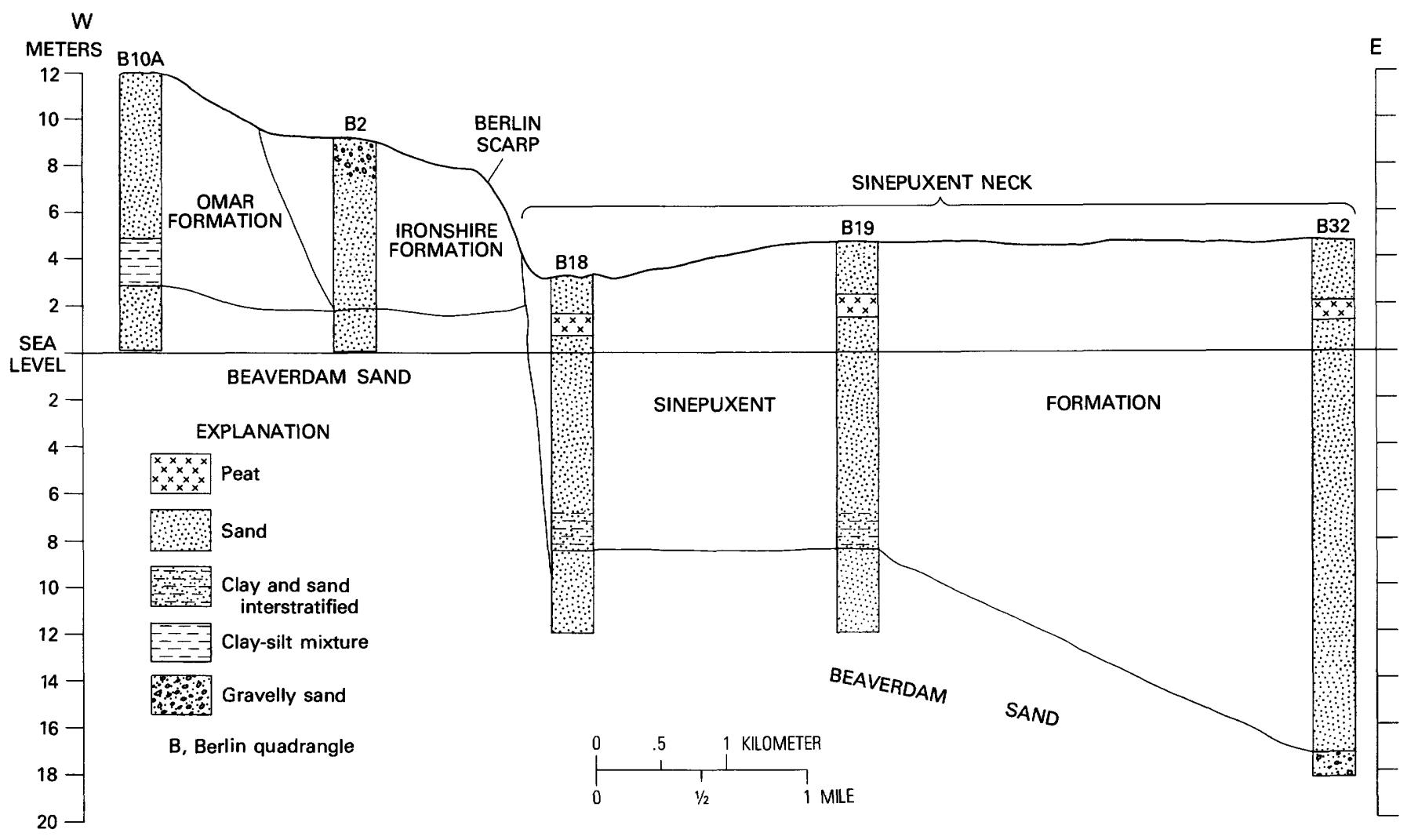

FIGURE 21.-Diagrammatic cross section near Berlin, Md., to show the Sinepuxent Formation lying against the Ironshire Formation and Beaverdam Sand along the Berlin scarp. Section based on samples from auger holes. 
tact between the two formations. The Sinepuxent thickens rapidly away from the scrap toward the ocean. The maximum thickness of this unit penetrated was more than $18 \mathrm{~m}(60 \mathrm{ft})$.

\section{HOLOCENE DEPOSITS}

Widespread but typically thin marine deposits of Holocene age fringe the Delmarva Peninsula and extend up major river valleys. These deposits were laid down during a large-scale transgression, which has been studied in detail by Kraft and his associates (Kraft, 1968, 1971; Kraft and others, 1973). Their well-documented conclusion provide a model for older transgressions. We have not attempted to add to their findings.

\section{ESTUARINE-FLUVIATILE AND EOLIAN UNITS}

The Delmarva Peninsula is bordered along Chesapeake and Delaware Bays by lowlands consisting of bay flats and broad valley bottoms which range in altitude from 0 to $15 \mathrm{~m}(0$ to $50 \mathrm{ft})$ above sea level. For the most part, the deposits underlying the surfaces of these landforms are thin, but locally they fill deep narrow channels. Many names have been given to these lowland deposits; for example, Talbot, Pamlico, or Princess Anne (fig. 3). Our studies indicate that the deposits in the lowlands do not form wave-built marine terraces of the sort envisioned by many earlier works. To avoid confusion, we have named and herein adopt the deposits in the lowland along Chesapeake Bay as the Kent Island Formation.

The lowland deposits on the east side of the peninsula have been discussed earlier with the Omar and Ironshire Formations. The estuarine-fluviatile facies of these units could be traced from these coastal marginal marine deposits into Delaware Bay. This is not true in the Chesapeake Bay region.

The larger rivers of the Delmarva Peninsula-the Pocomoke, Wicomico, Nanticoke, and Choptank-empty into Chesapeake Bay. In the river valleys is abundant reworked sediment. Because of the loose nature of this valley fill, however, most of it is featureless in a geomorphic sense. Well-defined terraces are not present in these valleys even though probably most, if not all, of the valleys have deposits associated with the major Quaternary transgressions and regressions (represented by the Omar, Ironshire, and Sinepuxent Formations). These valley-fill deposits will not be discussed in this report. In addition, eolian deposits are common on the south or east side of each of these rivers and their tributaries. A widespread eolian deposit also is present on the south side of the lower Delmarva Peninsula highland and to a lesser degree on the upland itself. These deposits are largely late Wisconsin in age and have been discussed in a separate report (Denny and Owens, 1978). Collectively, these eolian deposits have been mapped as the Parsonsburg Sand.

\section{KENT ISLAND FORMATION}

The western side of the Delmarva Peninsula is bordered by a broad (as much as $48 \mathrm{~km}$ ( 30 miles) wide) lowland, in which surface altitudes are from 0 to $7 \mathrm{~m}(0$ to $25 \mathrm{ft}$ ) above sea level. Most altitudes, however, are less than $3 \mathrm{~m}(10 \mathrm{ft})$. The general level of this lowland is lower than that of the lowland bordering the eastern side of the peninsula. A prominent west-facing scarp with a toe at an altitude of nearly $7 \mathrm{~m}(25 \mathrm{ft})$ separates the lowland from the higher terrain of the central peninsula to the east. The scarp extends from a point northeast of Kent Island in the upper bay to near Silver Beach, Va., in the lower bay, a distance of nearly $200 \mathrm{~km}$ (125 miles). The scarp, however, is interrupted at several places over this distance by streams, which have probably removed parts of it.

This lowland is extensively dissected. Narrow estuaries bordered by tidal marshes of Holocene age extend eastward from Chesapeake Bay across this lowland and into the central peninsula. Marshes are most extensive in an area south of Cambridge, Md., where the Holocene beds appear to be overlapping the lowland surface. Exposures of the sediments underlying the lowland within our mapped are sparse and usually only a few feet high. Exceptional exposures (as much as $4.5 \mathrm{~m}$ (15 ft) high) are found in bluffs on the north side of Kent Island along the Chester River. This area has been designated as the type area of the Kent Island Formation. Here the formation consists of thick beds of loose, light-colored cross-stratified sand that overlies dark-colored massive to thinly laminated clay-silt. Gravel as much as $10 \mathrm{~cm}$ (4 in.) in diameter occurs in thin beds with the sand or as scattered clasts in both the sand and clay-silt. Locally large tree stumps in growth position are encased within the clay-silt.

A cross section based on drill-hole data across Kent Island (fig. 22) shows that the formation is variable in lithology and thickness, thus resembling estuarine beds of the Ironshire Formation and parts of the Omar Formation in Delaware (fig. 20). The maximum thickness of this formation, on the basis of drilling at Kent Island, is

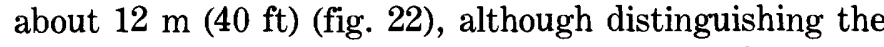
Kent Island beds in drill holes from underlying older Quaternary beds is difficult and in many areas impossible. In most areas the two units have been lumped together in construction of contour maps on the base of the Quaternary fill beneath the western peninsula lowlands. The Kent Island Formation varies considerably, however, in thickness beneath the lowland south of Kent Island. Large areas of the lowland have very thin deposits referrable to the Kent Island Formation. From Easton, 


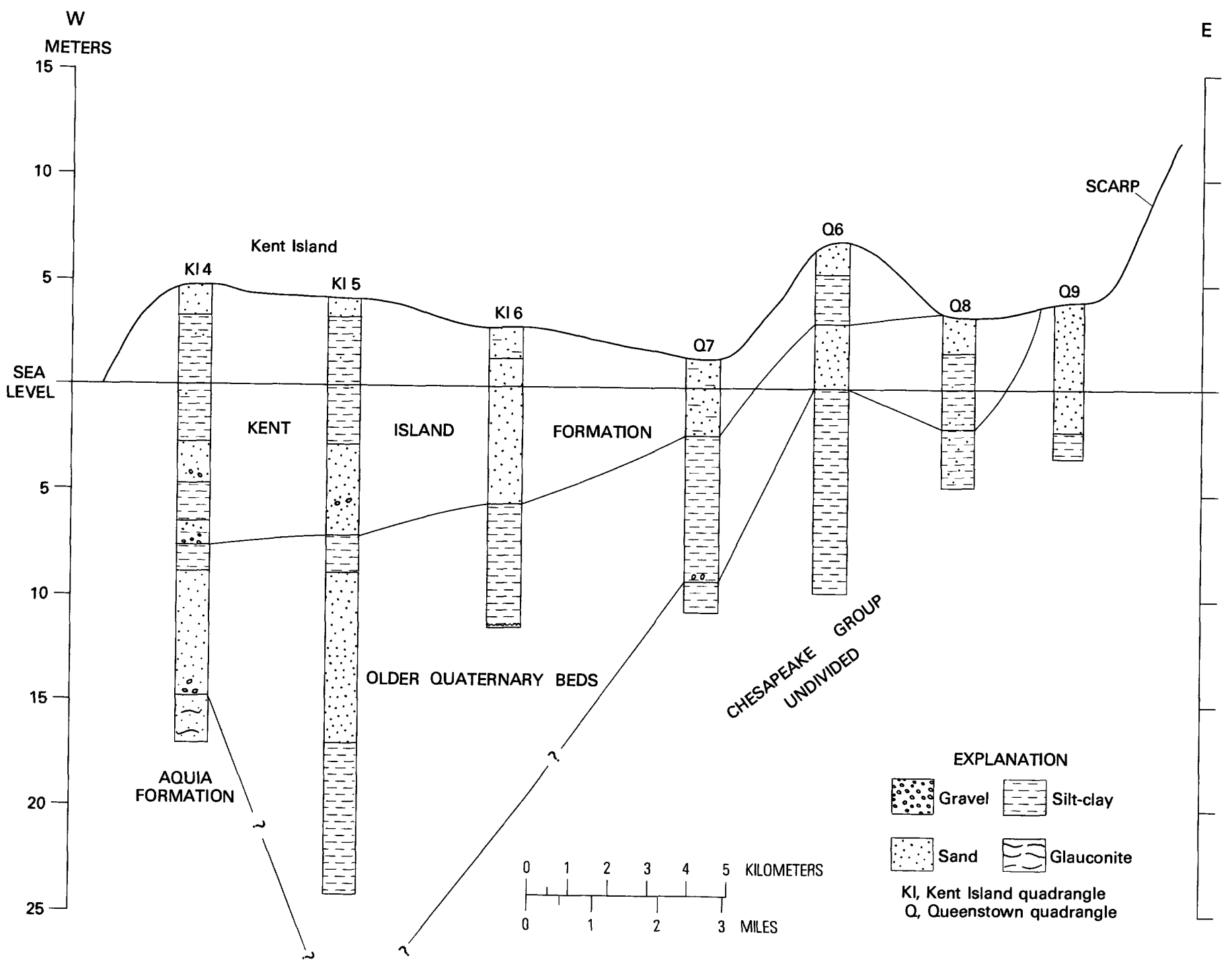

FIGURE 22.-Diagrammatic cross section showing the Kent Island Formation near Kent Island, Md. Section based on samples from auger holes.

Md., westward to the bay, for example, the underlying Chesapeake Group beds are only overlain by a few feet of Kent Island sediments. Downbay (southward), the Kent Island Formation is lithically as variable as at Kent Island, in part reflecting the lithology of the adjacent units. For example, near Cambridge, Md., where the Kent Island overlies and has entrenched into the clay-silt and sand of the lower part of the Chesapeake Group (Calvert(?) and Choptank Formations), the Kent Island beds are much more clayey than they are to the north. Farther south near Princess Anne, Md., where the underlying unit is in part the very sandy Beaverdam Sand, the Kent Island beds are much more sandy and gravelly than they are near Cambridge. In addition, throughout its length, the Kent Island Formation is very much more sandy adjacent to the scarp along the upland than it is near the bay. Here, long low ridges of clean loose sand parallel the scarp. In most areas where these ridges were drilled through, the sand overlies a thin basal peat.
North of Easton beneath one such ridge, the peat yielded an age of $30,000 \pm 1,000$ (W-3732). Also near Princess Anne, ridges of sand, circular in plan, are found on the Kent Island surface some distance away from the scarp. Some of the depressions enclosed by the sand ridges may be as much as $1.6 \mathrm{~km}$ (1 mile) in diameter. In Wicomico and Somerset Counties, Denny and others (1978) included these sand ridges in the the Parsonsburg Sand, in a middle-Wisconsin-age unit.

Petrologic studies of the sand in the Kent Island Formation showed a variation in composition (protoquartzite to subarkose). Locally, the heavy-mineral assemblages in the more feldspathic beds in the northernmost outcrops have large concentration of pyroxene (hence are very immature) and indicate addition of fresh sediment derived from crystalline rocks to the north or perhaps the west. In other sand beds, largely the protoquartzite sand, to the south or away from the main provenance, the heavy minerals are more mature, indicating a multi- 
cycle origin or local reworked Coastal Plain provenance. In general, the clay-mineral assemblages are similar throughout the whole formation and are a mixture of many clay types (kaolinite, illite, illite/smectite, smectite, and chlorite?). Vermiculite or chloritic vermiculite is very abundant in the clayey beds, particularly in the upper bay region.

No megainvertebrates or microfauna were found in the Kent Island Formation, but the bevelled older Quarternary units contain Crassostrea virginica and Rangia cuneata as far upbay as Taylors Islands. Fresh- and brackish-water diatoms have been found in the older beds even farther upbay, at least to Worton Point. Palynologic examinations were made of the dark clay in the Kent Island and the peat beneath the sand paralleling the scarp. The microflora is characterized by pine, birch, and alder; spruce or hemlock locally is a major constituent. Such a microflora indicates that a cool-temperate climate prevailed during the deposition of the Kent Island Formation (L. A. Sirkin, written commun., 1973). The microflora (oak-hickory assemblage mostly) in the underlying older Quaternary beds, in contrast, indicate a warmtemperate climate.

The Kent Island beds appear to have been deposited largely in an estuary-an expanded Chesapeake Bay. Freshwater conditions prevailed during the deposition of the Kent Island beds well down the bay, but the southern limit of freshwater conditions is still unknown. Apparently, currents in the estuary impinged against the western side of the peninsula, planing off a relatively flat surface on which very little sediment was deposited, particularly between Kent Island and Princess Anne. This erosion produced a scarp with a toe nearly $6 \mathrm{~m}(20 \mathrm{ft})$ above sea level along the west side of the peninsula for nearly $200 \mathrm{~km}$ (125 miles). Erosion and deposition were similar to processes now taking place on the west side of Chesapeake Bay. Locally, channels were cut in the flat floor of the estuary to depths well below sea level. The channels probably served as paths to carry much of the sediment downbay.

The Kent Island Formation is incised into and lies against the Chesapeake Group, the Pensauken Formation, the Beaverdam Sand, and probably the equivalent of the Ironshire and Omar Formations. The Kent Island, therefore, represents a major unconformity. Spatially, the Kent Island seems to be correlated with the Sinepuxent. This lowland surface probably was cut during the middle Wisconsin or Sinepuxent time; certainly the surface up to 3 to $4.5 \mathrm{~m}$ (10 to $15 \mathrm{ft}$ ) above sea level was formed during this interval. The Kent Island Formation is probably the old Chesapeake Bay bottom that preceded the formation of the modern Chesapeake Bay (a late Wisconsin regression, which was then followed by the now ongoing Holocene transgression).

\section{CONCLUSIONS}

A major purpose of our study of the central Delmarva Peninsula was to evaluate the marine-terrace hypothesis. This hypothesis, championed by Cooke $(1930,1958)$, supposed that on the Atlantic Coastal Plain, marine deposits that formed during high-level stands of the Quaternary seas reached a maximum height of $82 \mathrm{~m}(270 \mathrm{ft})$ above sea level. Our study has shown that this hypothesis is not applicable to the Delmarva Peninsula. The highest definite marine Pleistocene beds, which are lagoonal facies of a barrier-back-barrier sequence, are about 15 $\mathrm{m}(50 \mathrm{ft})$ above sea level. Shells dated radiometrically from this unit yielded an average age of 107,000 years, a Sangamon age, according to most time scales. Palynological studies show that these sediments have an overall microflora dominated by oak and hickory, indicating a warm-temperate climate not unlike that of the present.

West of this barrier sequence, the highest part of the central Delmarva Peninsula rises to altitudes 21-24 m $(70-80 \mathrm{ft})$ above sea level, where a deeply weathered, extensively dissected barrier-back-barrier sequence, the Walston Silt, is overlain locally by the Parsonsburg Sand. The Walston is important to the stratigraphy of this region because it contains a Tertiary flora characterized by the Asian walnut (Pterocarya), now extinct in North America. The presence of this Tertiary formation on the divide places an upper limit on the altitude attained by Pleistocene seas in this region. The precise age of the Walston cannot be pinpointed because no macroor microfauna has been found. On the basis of regional stratigraphic relationships, the Walston Silt is probably late Pliocene in age.

The Walston Silt overlies the Beaverdam Sand; therefore, both are Tertiary rather than Quaternary in age as has been commonly supposed. The lower beds of the Beaverdam appear to have been deposited in two channel systems, one coming from the direction of Chesapeake Bay, the other from the direction of Delaware Bay. Subsequently, these channels aggraded, and the deposits coalesced. The upper beds of the formation were deposited in a marginal marine environment, as evidenced by the trace fossils. Sedimentological studies of this formation suggest the introduction of very feldspathic sediment into both channels from an igneous or metamorphic province, or both.

The Beaverdam Sand unconformably overlies the Pensauken Formation and, hence, is younger. Most previous investigations suggested that these two units were time correlatives. The Pensauken appears to be the subaerial part of a large deltaic system that underlies much of the lower Delmarva Peninsula. The Pensauken interfingers with the subaqueous part of the delta, the "Yorktown and Cohansey(?)" Formations (Rasmussen and Slaughter, 1955). Fossils collected from the subaqueous facies 
indicate a late Miocene age for the "Yorktown and Cohansey(?)." The Pensauken Formation, therefore, is also late Miocene. In addition, the "Yorktown and Cohansey(?)" beds are older than the Yorktown Formation now thought to be early to middle Pliocene in age. Thus, the name "Yorktown and Cohansey(?)" (Rasmussen and Slaughter, 1955) seems inappropriate for the subaqueous beds.

The present configuration of the Delmarva Peninsula began to form in late Pleistocene time. About 100,000 years ago, sea level rose to about $15 \mathrm{~m}(50 \mathrm{ft})$ above its present position. A barrier-back-barrier sequence (Omar Formation) was deposited against the central part of the peninsula. The ancestral Chesapeake Bay contained marine and brackish waters at least as far north as the Choptank River and probably north of Kent Island.

After deposition of the Omar, another Sangamonian regressive-transgressive cycle took place, during which the Ironshire Formation was deposited. During this transgression, a well-defined scarp, with a toe nearly 6 $\mathrm{m}(20 \mathrm{ft})$ above sea level, was formed along the Atlantic Coast.

In middle-Wisconsin time (ca. 30,000 years), sea level

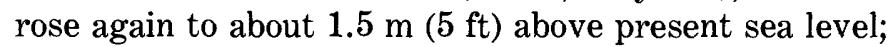
the Sinepuxent Formation was deposited at this time. This rise was followed by lowering of sea level during Wisconsin ice maximums.

The last major geologic event in the Delmarva region has been the Holocene transgression, during which the final outline of the peninsula has been shaped.

\section{REFERENCES CITED}

Berggren, W. A., 1972, A Cenozoic time-scale; some implications for regional geology and paleobiogeography: Lethaia, v. 5, no 2, p. 195-215.

Blackwelder, B. W., and Ward, L. W., 1976, Stratigraphy of the Chesapeake Group of Maryland and Virginia: Geol. Soc. America, Northeastern-Southeastern Sec. Mtg., Arlington, Va., 1976, Guidebook for Field Trip 7b, 55 p.

Coch, N. K., 1965, Post-Miocene stratigraphy and morphology, inner Coastal Plain, southeastern Virginia: U.S. Office Naval Research, Geography Branch, Contract NONR 609(40), Tech. Rept. 6, [146] p.

Cooke, C. W., 1930, Correlation of coastal terraces: Jour. Geology, v. 38 , no. 7 , p. $577-589$.

- 1958, Pleistocene shorelines in Maryland: Geol. Soc. America Bull., v. 69 , no. 9, p. $1187-1190$.

Cushing, E. M., Kantrowitz, I. H., and Taylor, K. R., 1973, Water resources of the Delmarva Peninsula: U.S. Geol. Survey Prof. Paper $822,58 \mathrm{p}$.

Denny, C. S., and Owens, J. P., 1978, Sand dunes on the central Delmarva Peninsula, Maryland and Delaware: U.S. Geol. Survey Prof. Paper 1067-C. (In press.)

Denny, C. S., Owens, J. P., Sirkin, L. A., and Rubin, Meyer, 1978, The Parsonsburg Sand in the central Delmarva Peninsula, Maryland and Delaware: U.S. Geol. Survey Prof. Paper 1067-B. (In press.)
Flint, R. F., 1940, Pleistocene features of the Atlantic Coastal Plain: Am. Jour. Sci., v. 238, no. 11, p. 757-787.

Gernant, R. E., 1970, Paleoecology of the Choptank Formation (Miocene) of Maryland and Virginia: Maryland Geol. Survey Rept. Inv. $12,90 \mathrm{p}$.

Glaser, J. D., 1971, Geology and mineral resources of southern Maryland: Maryland Geol. Survey Rept. Inv. 15, $85 \mathrm{p}$.

Hack, J. T., 1955, Geology of the Brandywine area and origin of the upland of southern Maryland: U.S. Geol. Survey Prof. Paper 267A, p. $1-43$.

1957, Submerged river system of Chesapeake Bay: Geol. Soc. America Bull., v. 68, no. 7, p. 817-830.

Hansen, H. J., 3d, 1966, Pleistocene stratigraphy of the Salisbury area, Maryland, and its relationship to the lower Eastern Shore-A subsurface approach: Maryland Geol. Survey Rept. Inv. 2, 56 p.

Hazel, J. F., 1979, Age and correlation of the Yorktown (Pliocene) and Croatan (Pliocene and Pleistocene) Formations at the Lee Creek, North Carolina, open-pit mine: Smithsonian Inst. Contr. Paleobiology. (In press.)

Johnston, R. H., 1973, Hydrology of the Columbia (Pleistocene) deposits of Delaware; an appraisal of a regional water-table aquifer: Delaware Geol. Survey Bull. 14, 78 p.

Jordan, R. R., 1962, Stratigraphy of the sedimentary rocks of Delaware: Delaware Geol. Survey Bull. 9, $51 \mathrm{p}$.

Jordan, R. R., and others, 1967, Delaware-Guidebook, Atlantic Coastal Plain Geological Association, 8th Annual Field Conference: Newark, Del., Univ. Delaware and Delaware Geol. Survey, [20] p., appendices and road log.

Kraft, J. C., 1968, Coastal sedimentary environments, Lewes-Rehoboth Beach, Delaware-Soc. Econ. Paleontologists and Mineralogists Guidebook, Northeastern Sec., 1968, Field Trip: Newark, Del., Univ. Delaware, Dept. Geology [13 p.].

- 1971, Sedimentary facies patterns and geologic history of a Holocene marine transgression: Geol. Soc. America Bull., v. 82, no. 8, p. 2131-2158.

Kraft, J. C., Biggs, R. B., and Halsey, S. D., 1973, Morphology and vertical sedimentary sequence models in Holocene transgressive barrier systems, in Coates, D. R., ed., Coastal geomorphologyA proceedings volume of the Third Annual Geomorphology Symposia Series, held at Binghamton, New York, September 28-30, 1972: Binghamton, N.Y., State Univ. New York, Pubs. in Geomorphology, p. 321-254.

Leopold, E. B., 1969, Late Cenozoic palynology, [Chap.] 17 in Tschudy, R. H., and Scott, R. A., eds., Aspects of palynology: New York, Interscience Publishers, p. 377-438.

Mack, F. K., Webb, W. E., and Gardner, R. A., 1971, Water resources of Dorchester and Talbot Counties, Maryland: Maryland Geol. Survey, Rept. Inv. 17, 107 p.

Mansfield, W. C., 1943, Stratigraphy of the Miocene of Virginia and the Miocene and Pliocene of North Carolina in Gardner, Julia, Mollusca from the Miocene and lower Pliocene of Virginia and North Carolina: U.S. Geol. Survey Prof. Paper 199-A, p. 1-19.

McGee, W J, 1888, Three formations of the Middle Atlantic slope: Am. Jour. Sci., 3d ser., v. 35, p. 120-143, 328-330, 367-388, $448-466$.

Miller, B. L., 1920, Stratigraphy of the Coastal Plain formations, in Bascom, Florence, and Miller, B. L., Description of the ElktonWilmington quadrangle (Md.-Del.-N.J.-Pa.): U.S. Geol. Survey Geol. Atlas, Folio 211, p. 8-17.

Oaks, R. Q., Jr., and Coch, N. K., 1973, Post-Miocene stratigraphy and morphology, southeastern Virginia: Virginia Div. Mineral Resources Bull. $82,135 \mathrm{p}$.

Owens, J. P., and Minard, J. P., 1975, Geologic map of the surficial deposits in the Trenton area, New Jersey and Pennsylvania: U.S. Geol. Survey Misc. Geol. Inv. Map I-884. 
1978, Late Cenozoic sediments of the lower Delaware Valley and the northern Delmarva Peninsula, New Jersey, Pennsylvania, Delaware, and Maryland: U.S. Geol. Survey Prof. Paper 1067-D (In press.)

Owens, J. P., Stefansson, Karl, and Sirkin, L. A., 1974, Chemical, mineralogic, and palynologic character of the upper Wisconsinanlower Holocene fill in parts of Hudson, Delaware, and Chesapeake estuaries: Jour. Sed. Petrology, v. 44, no. 2, p. 390-408.

Rachele, L. D., 1974, Palynology of the Legler lignite: New York, New York Univ., unpub. thesis.

Rasmussen, W. C., and Slaughter, T. H., 1955, The ground-water resources, in The water resources of Somerset, Wicomico, and Worcester Counties: Maryland Dept. Geology, Mines and Water Resources Bull. 16, p. 1-170.

1957, The ground-water resources in The water resources of Caroline, Dorchester, and Talbot Counties: Maryland Dept. Geology, Mines and Water Resources, Bull. 18, p. 1-371, 447-465.

Rasmussen, W. C., Wilkens, R. A., and Beall, R. M., and others, 1960, Water resources of Sussex County, Delaware, with a section on salt-water encroachment at Lewes: Delaware Geol. Survey Bull. $8,228 \mathrm{p}$.

Richards, H. G., and others, 1965, INQUA Field Conference B-1, Central Atlantic Coastal Plain, in Internat. Assoc. Quaternary Re- search, 7th Cong., Denver and Boulder, Colo., 1965, Guidebook for Field Conference B-1***and Field Conference B-3***. Edited by C. B. Schultz and H. T. U. Smith: Lincoln, Nebr., Nebraska Acad. Sci., p. 5-28.

Schlee, J. S., 1957, Upland gravels of southern Maryland: Geol. Soc. America Bull., v. 68 , no. 10, p. 1371-1409.

Shattuck, G. B., 1901, The Pleistocene problem of the North Atlantic Coastal Plain: Johns Hopkins Univ. Circ. 20, p. 69-75; Am. Geologist, v. 28 , p. 87-107.

1902, The geology of the Coastal Plain formations, in The physical features of Cecil County: Maryland Geol. Survey, Cecil County [Volume], p. 149-194.

1906, The Pliocene and Pleistocene deposits of Maryland: Maryland Geol. Survey, Pliocene and Pleistocene [Volume], p. 21-137.

Spoljaric, Nenad, 1967, Pleistocene channels of New Castle County, Delaware: Delaware Geol. Survey Rept. Inv. 10, $15 \mathrm{p}$.

Weigle, J. M., 1972, Exploration and mapping of Salisbury paleochannel, Wicomico County, Maryland: Maryland Geol. Survey Bull. 31, pt. 2, p. 61-123.

1974, Availability of fresh ground water in northeastern Worcester County Maryland; with special emphasis on the Ocean City area: Maryland Geol. Survey Rept. Inv. 24, 63 p. 